Article

\title{
The White Marbles of the Tomb of Christ in Jerusalem: Characterization and Provenance
}

\author{
Antonia Moropoulou ${ }^{1, *}$, Ekaterini T. Delegou ${ }^{1}$, Maria Apostolopoulou ${ }^{1}$, Aikaterini Kolaiti ${ }^{1}$, \\ Christos Papatrechas ${ }^{2}$, George Economou ${ }^{2}$ and Constantinos Mavrogonatos ${ }^{3}$ (i) \\ 1 Laboratory of Materials Science and Engineering, School of Chemical Engineering, National Technical \\ University of Athens, 15780 Athens, Greece; edelegou@central.ntua.gr (E.T.D.); \\ mairi_apostol@hotmail.com (M.A.); kolaitik@gmail.com (A.K.) \\ 2 Institute of Geology and Mineral Exploration (I.G.M.E.), 13677 Athens, Greece; \\ papatrechas@windowslive.com (C.P.); georgeoik7@gmail.com (G.E.) \\ 3 Department of Geology \& Geoenvironment, National and Kapodistrian University of Athens, 15784 Athens, \\ Greece; kmavrogon@geol.uoa.gr \\ * Correspondence: amoropul@central.ntua.gr; Tel.: +30-210-7723276
}

Received: 9 March 2019; Accepted: 23 April 2019; Published: 28 April 2019

\begin{abstract}
In this work, samples of the white marbles enclosing the Tomb of Christ, as well as samples from the interior marble facades of the Holy Aedicule structure surrounding the Tomb of Christ in the Church of Resurrection in Jerusalem, are investigated using petrographic and isotopic analysis. The aim is to characterize the marble samples and investigate their provenance. The results demonstrate that all examined marble samples originate from Proconnesos (Marmara island), and can be attributed to the so-called Proconnesos-1 variety. Published maximum grain size (MGS) and isotopic $\left(\delta^{18} \mathrm{O}\right.$ and $\left.\delta^{13} \mathrm{C}\right)$ values of Proconessos quarries are compared with the respective values displayed by the marble samples of the Holy Aedicule, aiming to achieve- to a certain degree-intra-site discriminations. A number of ancient quarries are excluded through this double parameter criterion as sources for the examined Holy Aedicule marbles. The discussion of petrographic and isotopic results in relation to historical testimonies and previously published archaeometry results, regarding the mortars of the Holy Aedicule, reveal that Proconnesos marble was the material of choice used at different construction phases of the Holy Aedicule, from the time of Constantine the Great and throughout the centuries, both for the cladding of the Holy Tomb and the interior facings of the Tomb Chamber and the Chapel of the Angel.
\end{abstract}

Keywords: Holy Sepulchre; Church of Resurrection; petrography; isotopic analysis; Proconnesos; cultural heritage; monument; history; archaeometry

\section{Introduction}

Natural rocks have been used as a raw material for constructive and decorative purposes since antiquity. Many rock-types have been selected for these purposes, (e.g., chert, granite, gneiss, schists, serpentinite, etc.), but undoubtedly, marble has been the most prominent type [1], especially concerning monumental, religious and important buildings. Marbles are metamorphic rocks, consisting almost entirely of calcite, with minor admixture of a number of accessory minerals. In the broad Mediterranean region, marble mining activities have been documented since the Neolithic period, with constantly increasing rates of exploitation, which flourished during the Greco-Roman period [1].

White and colored marbles have been long known as a favorite building and decoration material of the ancient times. The provenance identification of the raw materials used during antiquity, is a matter of great significance to both historians and archaeologists [2], as well as to other scientists in the 
field of monument protection. This is not only because such results could lead towards understanding commercial and socio-economic relations (e.g., trade routes) among ancient populations, but because it could also provide the proper material for conservation and restoration interventions in damaged monuments and sculptures [3]. Especially for marbles, which were preferably used as raw material for sculpturing, building and decoration purposes, attempts to determine their provenance date back to the end of the 19th century. At that time, Lepsius (1890) [4], was the first who tried to use "scientific" criteria in order to define the provenance of marble-curved items, based mostly on their macroscopic characterization, an approach which later proved to be erroneous and/or inadequate. Since then, and especially during the last three decades, archaeometric studies have expanded significantly beyond macroscopic examination, by including new analytical techniques or combinations of more than one technique, in order to obtain more accurate results $[2,3,5,6]$.

Petrographic investigation of rock samples is among the first truly scientific methods applied for provenance determination [7-10], because it is indicative of the environment of marble formation. This method comprises a number of parameters related to the mineralogy and the fabric of the rock. The mineralogical examination aims to identify the main and the accessory mineral phases that compose the rock. Beyond calcite and less commonly dolomite, which often exceed $95 \%$ of the rock volume, a number of accessory phases have been described for many marbles around the world [11]. In addition, the fabric of the studied sample gives significant information and may be critical in the identification of various rock types, as it reflects the degree of rock deformation, mostly expressed by the maximum grain size (MGS) and the grain boundary shape (GBS). These two parameters, coupled with the mineralogical content, provided encouraging results, but soon proved to be inadequate for a secure provenance determination. This is due to: (i) the great number of accessory minerals that were commonly identified; and (ii) the sometimes significant inhomogeneity of rock samples from the same quarry (e.g., differences in the dolomite content, grain size variations, etc.) [12].

Geochemical analyses, which focus on measuring minor (e.g., Na, Mn) and trace (e.g., REE) elements' concentrations, commonly conducted by neutron activation analysis (NAA) or inductively-coupled plasma mass spectrometry (ICP-MS) resulted in a number of significant geochemical data sets. Unfortunately, the inhomogeneous content of marbles in the aforementioned chemical impurities, as well as the overlapping of many data sets from different areas, again proved to be discouraging in relation to provenance determination.

Measuring the isotopic ratios of $\mathrm{C}$ and $\mathrm{O}$ in marble samples, was proposed by Craig and Craig, (1972) [13], and, since then, it is considered, along with petrographic analysis (and/or other analytical techniques), the most classic approach in archaeometry studies, especially for marble artifacts. This combination of methods commonly suffices and results in reliable data sets which allow scientists to make a relatively safe identification. Other analytical methods comprise cathodoluminescence, which is related to the impurities of Fe and $\mathrm{Mn}$, electronic spin resonance and electronic paramagnetic resonance (ESR/EPR), as well as strontium isotopic measurements. Although the aforementioned methods usually provide additional information, they cannot be used alone, as they remain unreliable in attributing a marble artifact to its quarry of origin [12]. Moreover, the high cost of the Sr-isotopic measurements is often a reason for researchers to avoid this method. X-ray diffraction (XRD) and electron-probe micro-analysis (EPMA) are two methods commonly used to obtain mineral-chemical data, especially for accessory phases that could be used as pathfinders towards the provenance identification of the sample [11,14].

The last decades, the Association for the Study of Marbles and Other Stones in Antiquity (ASMOSIA) and its members have provided a very useful dataset and have proposed new methodological approaches for the provenance identification problem. Based mostly on isotopic and petrographic characterizations, a number of researchers have published detailed studies, especially for the most common marble types used in antiquity and have provided accurate datasets that compare artifact samples and geological material. These studies refer mainly to the Proconnesian 
(Marmara island) marble [15,16], the Thasian marble [17], the Carrara [18], the Parian marbles [19], the Aphrodisias marble [20] and the Pentelic marble [21-23].

Among the many marble-producing areas during the ancient times, some have proved to be major producers, due to the quality of their material and on account of their location on important trade routes or their vicinity to important ancient cities. In the case of white marbles, the most important quarrying locations around the Mediterranean are scattered mainly in what is now modern Greece, Turkey and Italy (Figure 1). The most important and frequently used white marbles since antiquity are the white marbles from Penteli, in Greece, from the Greek islands of Thasos and Paros, the Italian Carrara marble, as well as the Proconnesos marble from modern day Turkey.

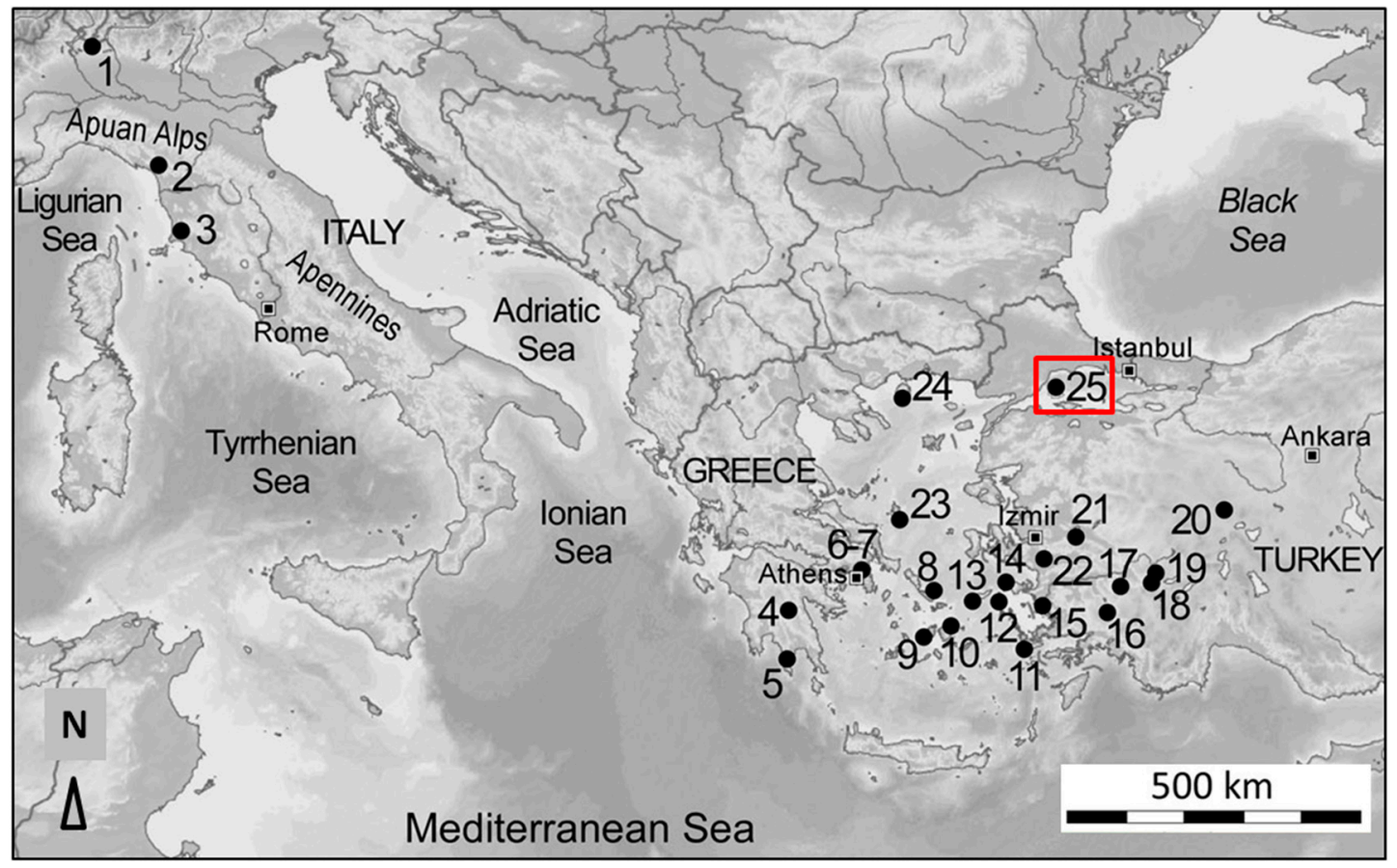

Figure 1. Map of the eastern Mediterranean region indicating the locations of ancient quarrying sites, modified after Antonelli and Lazzarini 2015 [12]: (1) Candoglia; (2) Carrara; (3) Campiglia; (4) Doliana; (5) Mani; (6-7) Mts Pentelic and Hymettus; (8) Tinos; (9) Paros; (10) Naxos; (11) Kos; (12) Fourni; (13) Ikaria; (14) Samos; (15) Miletus; (16) Göktepe; (17) Aphrodisia; (18) Denizli; (19) Thiounta; (20) Docimium; (21) Sardis; (22) Ephesos; (23) Skyros; (24) Thasos; (25) Proconnesos (Marmara), indicated by red rectangular.

Pentelic marble is perhaps the most famous marble used in ancient monuments, due to its excellent quality; in classical Athens it was the material of choice, used for the construction of the Parthenon in Athens and the Hephaestus Temple in the Ancient Athenian Agora [13,24,25]. Its use was continuous throughout the ages, as it also adorns important neoclassical buildings of the 19th and 20th century in Athens [26].

Parian marble was used in various monuments in the ancient Greek and Roman world and was highly appreciated [27]. Owing to its high purity and texture, it was used in decorative elements, for example the decorative reliefs of the ancient Temple of Hephaestus in Athens, as well as important sculptures [28] and anthropomorphic sarcophagi [29]. Thasian marble was also widely used, in monuments (such as the burial monument of Amphipolis in Macedonia, Greece), as well as in Greek and Roman statues and reliefs [30]. Carrara marble has been used in monumental roman structures, such as the Pantheon and Trajan's column, roman sculptures, and sculptures of the Renaissance, such as Michalangelo's David, as well as in more recent monumental, religious and important buildings throughout the world [31-33]. 
The northern side of Proconnesos Island has been well known as a major marble producing area since the archaic period [34]. Its production spiked during the Roman times, around the second half of the first century $\mathrm{AD}$, while the local quarries were made dependent on the imperial treasury by Hadrian. In the fourth century, the quarries produced ready-to-sculpt blocks and building elements, tied to the large imperial buildings of Constantine the Great [35]. Proconnesos marble, due to its appearance and quality, was a greatly appreciated marble. In addition, the insular nature of its quarries from which marble could be directly transported by sea, greatly reduced transportation costs, thus increasing its popularity [35]. In addition, the vicinity of the quarries to Constantinople, the capital city of the Byzantine empire, made the Proconnesian marble one of the most popular raw materials during the Byzantine times $[16,36]$. Proconnesian marble has been used in numerous monuments, sculptures and sarcophagus throughout the ages [37-41], as well as in important modern-day buildings.

A relatively recent study regarding the provenance of the marbles comprising the Sanctuary of the Great Gods in Samothrace presented a complex pattern of provenance including Thasian, Pentelic, Parian and Proconnesian marble, sometimes in combination [42]. This is true for many monuments, as reuse of older members from other monumental buildings is usual throughout all historical periods, an issue which complicates provenance studies.

The great importance of the above mentioned marble monuments, as well as the complexity of their construction and multiple construction/restoration phases, implies that accurate provenance identification is a very critical field of research; not only for restoration purposes, but also because it can broaden conceptions and interpretations in relation to historical and archaeological aspects regarding the selection, transportation and use-or even re-use - of this valuable material. In this framework, the provenance of marbles used in monumental buildings, such as the Holy Aedicule, is especially interesting and is herein addressed.

The Holy Aedicule is an indoor structure located in the center of the Rotunda area in the Church of Resurrection in Jerusalem (Figure 2a). It is the structure surrounding and containing what is believed to be the Tomb of Christ and is thus a religious site of great importance for the Christian World. The Holy Aedicule today consists of two chambers; the Chapel of the Angel to the east and the Holy Tomb Chamber to the west (Figure $2 b$ ). The exterior of the structure is covered with stone facings, consisting of locally quarried compact stones (mizzy and slayeb stones) (Figure 3) [43-45]. The interior of both chambers is adorned with marble facings, mostly of white coloration (Figure 4a, b). The Tomb of Christ, located at the northern side of the Tomb Chamber, is also enclosed within marble facing (Figure 4b).
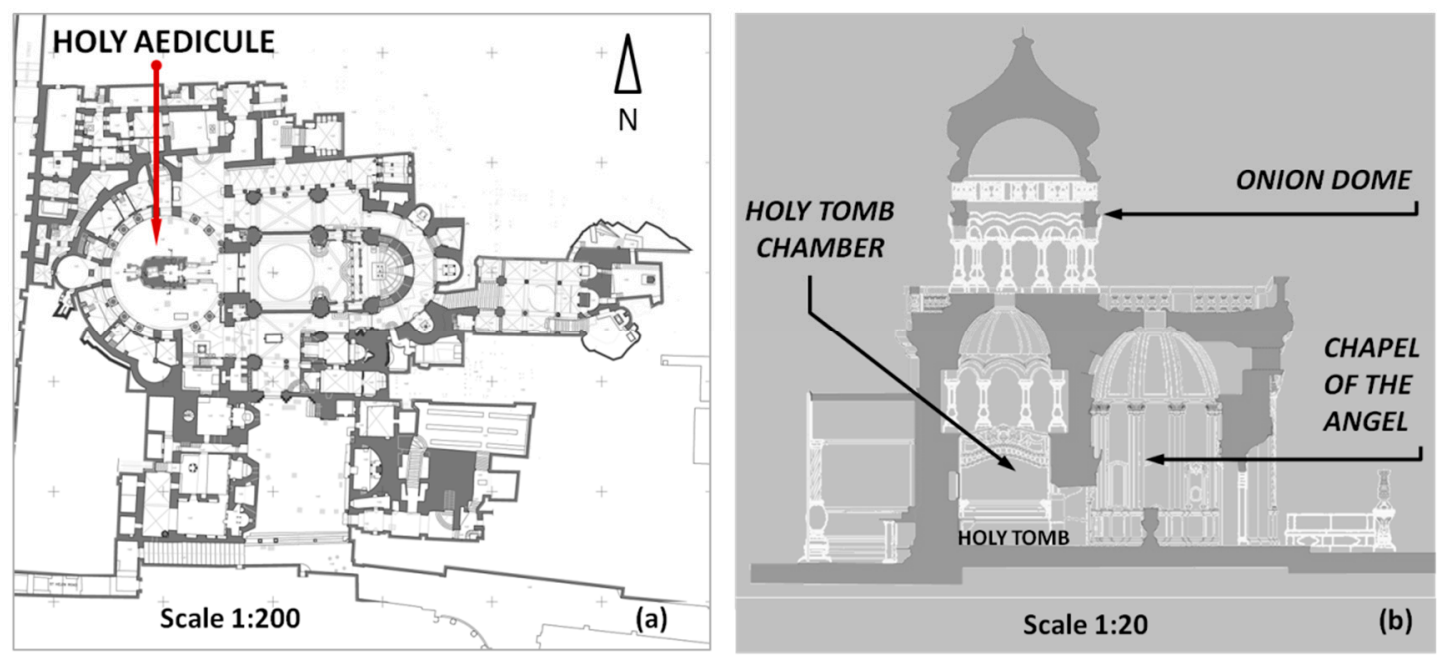

Figure 2. (a) Ground plan of the Church of Resurrection in Jerusalem, indicating the location of the Holy Aedicule within the Rotunda area, modified after Lavvas 2009 [46]; (b) Section of the Holy Aedicule North view, indicating the basic parts of the structure, modified after Balodimos et al 2003 [47], Lavvas 2009 [46]. 

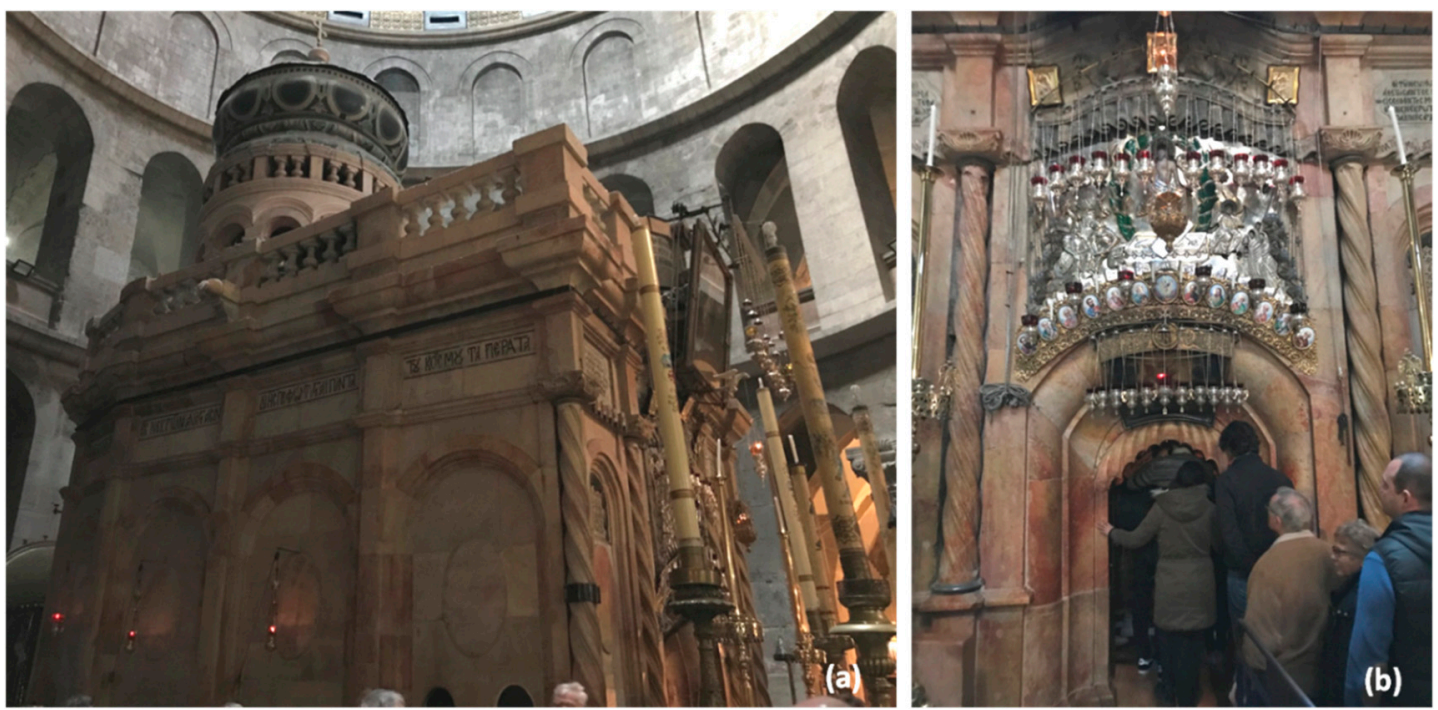

Figure 3. (a) View of the South façade of the Holy Aedicule as it is today; (b) The main entrance of the Holy Aedicule from the East, where the pilgrims enter.
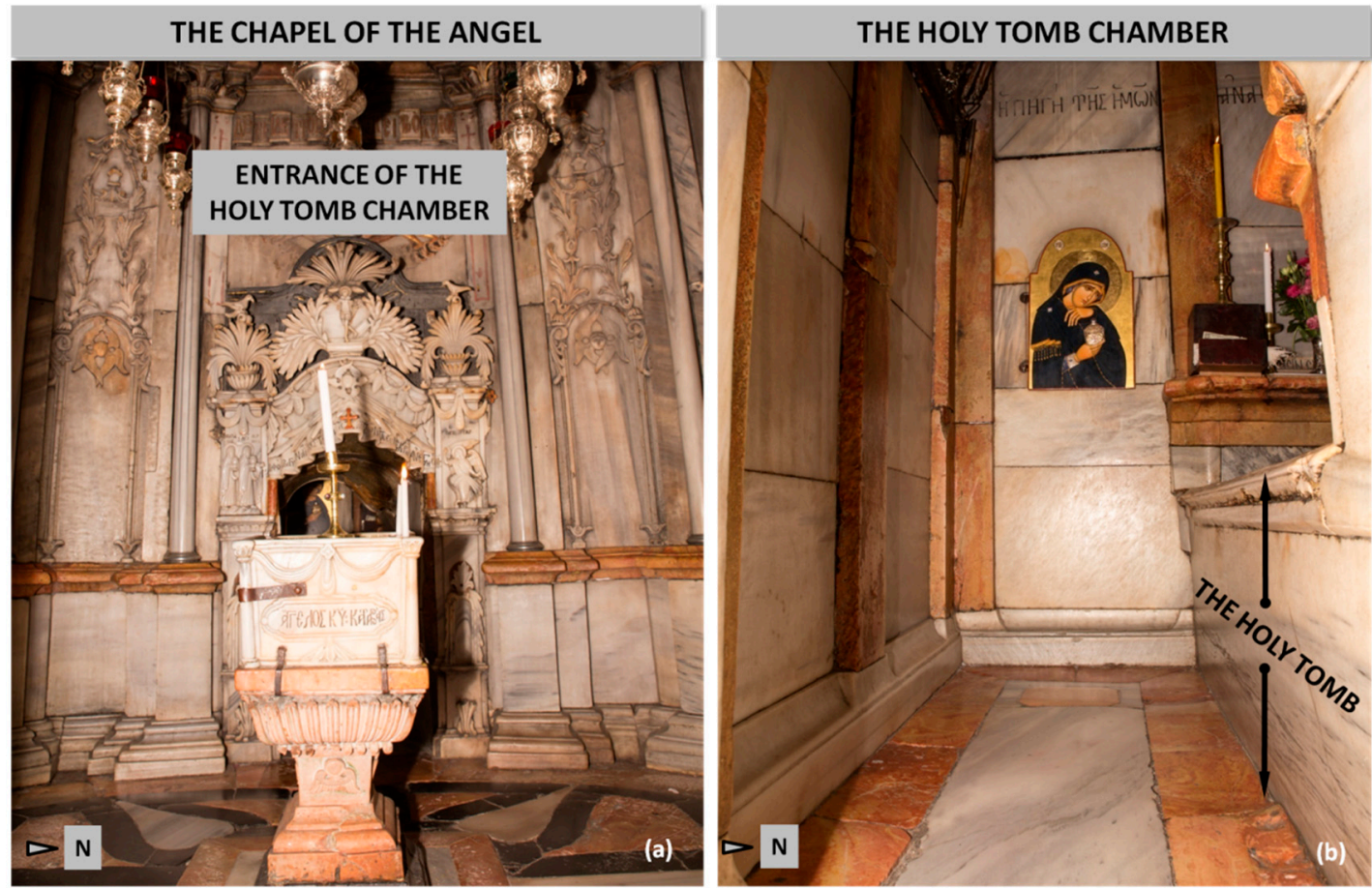

Figure 4. (a) Interior west façade of the Chapel of the Angel, showing the low entrance to the Tomb Chamber, with the marble pedestal containing part of the stone of the Angel; (b) Tomb Chamber adorned with marble facings; the Holy Tomb is indicated on the right-hand side of the image.

In addition to its religious significance, it is also a site of high archaeological and architectural interest, as its evolution during the last 17 centuries reflects and embeds the tumultuous history of the city of Jerusalem. Since the fourth century AD, when the cave-hewn Tomb was uncovered by Saint Helena and Constantine the Great and enclosed within a structure (Aedicule), it has evolved into the complex structure that stands today, visited by millions of pilgrims annually [48]. The major historical events, constructions, destructions and subsequent reconstructions which mark the evolution of the Holy Aedicule structure are presented in Table 1. 
Table 1. Major historical phases of the Holy Aedicule-Construction, Destructions and Restorations.

\begin{tabular}{|c|c|}
\hline Chronology & $\begin{array}{l}\text { Major Historical Phases of the Holy Aedicule-Construction, Destructions and } \\
\text { Restorations }\end{array}$ \\
\hline 136-137 AD: & $\begin{array}{l}\text { At the site of the rock-cut Tomb of Christ, the Roman Emperor Hadrian builds a Capitol } \\
\text { (Capitolium), as a statement of Roman domination and power. Eusebius } \\
\text { (260/265-339/340 AD) mentions: "Indeed with a great expenditure of effort they brought } \\
\text { earth from somewhere outside and covered up the whole place, then leveled it, paved it, and so } \\
\text { hid the divine cave somewhere down beneath a great quantity of soil" [49]. }\end{array}$ \\
\hline 325-326 AD: & $\begin{array}{l}\text { Constantine the Great and Saint Helena discover the Tomb of Christ, which they } \\
\text { uncover and enclose in a structure, known as the Holy Aedicule. Constantine requests } \\
\text { that: "the building should surpass all the Churches in the world, in the beauty of its walls, its } \\
\text { columns and marbles" [50]. } \\
\text { Regardless of controversy as to the form of the Constantinean Aedicule-no entirely } \\
\text { realistic depiction of this Aedicule is available-it is widely accepted that the Holy } \\
\text { Tomb was at this point in the form of a polygonal ciborium-type structure (Aedicule) } \\
\text { consisting of the burial chamber [ } 49,51] \text {. }\end{array}$ \\
\hline 614 AD: & $\begin{array}{l}\text { The Persians conquer the city of Jerusalem and infer severe damages on the Church of } \\
\text { Resurrection [52] }\end{array}$ \\
\hline 626-630 AD: & $\begin{array}{l}\text { In 626, Modestos, who was at the time standing in as Patriarch of Jerusalem, begins the } \\
\text { reconstruction of the Church of Resurrection, which was concluded after four years, } \\
\text { allowing Heraclius, to make a victorious ceremonial entry into Jerusalem on } 21 \text { March 630, } \\
\text { carrying the precious relic of the True Cross, as the trophy of victory, and reinstall it in the } \\
\text { church of the Holy Sepulchre [53-57]. There is no certain knowledge whether the } \\
\text { Aedicule itself sustained any damage or whether any repairs were required [51]. In any } \\
\text { case, the Aedicule remains in the form of a polygonal ciborium-type structure. }\end{array}$ \\
\hline 1009 AD: & $\begin{array}{l}\text { The Fatimid Caliph, al-Hākim bi-Amr Allāh, conquers Jerusalem and nearly destroys } \\
\text { the Holy Pilgrimage Sites [57]. Hakim ordered Yaruk, governor of Ramla, to "demolish } \\
\text { the church of the Resurrection and to remove its (Christian) symbols, and to get rid of all traces } \\
\text { and remembrance of it." Yaruk's son and two associates "seized all the furnishings that were } \\
\text { there, and knocked the church down to its foundations, except for what was impossible to destroy } \\
\text { and difficult to grub up to take away" (according to [51]). }\end{array}$ \\
\hline 1012-1023 AD: & $\begin{array}{l}\text { Al Hakim's Christian mother, Maria, begins to "rebuild with well-dressed squared stones } \\
\text { the Temple of Christ destroyed by her son's order" [51]. }\end{array}$ \\
\hline 1037-1040 AD: & $\begin{array}{l}\text { Major reconstruction takes place, following a strong earthquake in 1034, either during } \\
\text { the time of the Byzantine Emperor Michael IV the Paphlagonian (1034-41 CE), or } \\
\text { during the reign of Emperor Constantine IX Monomachos (1042-1048 CE) or } \\
\text { both [51,58]; the exact dates of the 11th century Byzantine interventions are still under } \\
\text { debate. Up to this point the Aedicule remains in a polygonal form. }\end{array}$ \\
\hline 1099-1187 AD: & $\begin{array}{l}\text { The Crusaders expand the Aedicule to the east through the addition of an antechamber, } \\
\text { the Chapel of the Angel, at the spot where the Angel appeared after the burial of Jesus } \\
\text { Christ, according to the Gospels, thus leading to the characteristic, since then, } \\
\text { horse-shoe shape of the Aedicule }[51,57] \text {. }\end{array}$ \\
\hline 1244 AD: & $\begin{array}{l}\text { Khwarismian horsemen sweep down from the north-west, and enter Jerusalem. } \\
\text { According to testimonies, "the Khwarismians entered the Church of the Holy Sepulchre, } \\
\text { broke open the tombs of the kings, slaughtered the Christians who had taken refuge in front of } \\
\text { the Edicule, decapitated the priests who were celebrating at the altars, and laying sacrilegious } \\
\text { hands on the tomb of the Lord's resurrection, they defiled it in many ways, overturning from its } \\
\text { base the marble cladding placed around it... The carved columns placed in front of the tomb of } \\
\text { the Lord for decoration, they removed, sending them as a sign of victory to the tomb of the evil } \\
\text { Mohammed, to the disgrace of the Christians" [51]. }\end{array}$ \\
\hline
\end{tabular}


Table 1. Cont.

\begin{tabular}{|c|c|}
\hline Chronology & $\begin{array}{l}\text { Major Historical Phases of the Holy Aedicule-Construction, Destructions and } \\
\text { Restorations }\end{array}$ \\
\hline 1555 AD: & $\begin{array}{l}\text { Major restoration of the Holy Aedicule by Fra Bonifacio da Ragusa, the Custos of the } \\
\text { Franciscan Order [59]. Restoration was crucial, not only owing to the fact that the } \\
\text { Aedicule structure had not been restored in } 500 \text { years and was thus in a deteriorated } \\
\text { state, but was also necessitated due to damages inferred by strong earthquakes ( } 1453 \\
\text { AD, } 1545 \text { AD) [51,57]. It is possible that, although Bonifacio states that the } \\
\text { reconstruction was from the foundation, in fact, only the Dome was reconstructed, in } \\
\text { addition to the repositioning of several members of the structure. }\end{array}$ \\
\hline 1808 AD: & $\begin{array}{l}\text { A large fire breaks out in the Church of Resurrection, causing the Rotunda dome to } \\
\text { collapse, affecting the Aedicule as well }[51,57] \text {. }\end{array}$ \\
\hline 1809-1810 AD: & $\begin{array}{l}\text { The architect Kalfa Komnenos restores the Holy Aedicule, giving it its present form. } \\
\text { Although he states that it was rebuilt from the foundations, there is probability that the } \\
\text { fire did not affect the interior of the Holy Aedicule }[51,57] \text {. }\end{array}$ \\
\hline 1947 AD: & $\begin{array}{l}\text { An external iron frame is installed by the British Mandate in } 1947 \text {, as a temporary } \\
\text { solution, to address the severe deformations of the Holy Aedicule structure, observed } \\
\text { already as early as 1927, and to prevent the collapse of the Aedicule }[51,60] \text {. }\end{array}$ \\
\hline 2015 AD: & $\begin{array}{l}\text { The National Technical University of Athens (NTUA) was invited by His Beatitude, } \\
\text { Patriarch of Jerusalem Theophilos III, to implement an "Integrated Diagnostic Research } \\
\text { Project and Strategic Planning for Materials, Interventions Conservation and } \\
\text { Rehabilitation of the Holy Aedicule of the Church of the Holy Sepulchre in Jerusalem" } \\
\text { [61] in order to ascertain as to the causes for the severe buckling and serious } \\
\text { deformations of the structure and design rehabilitation proposals. }\end{array}$ \\
\hline 2016-2017 AD: & $\begin{array}{l}\text { A historical Common Agreement of the three Christian Communities responsible for } \\
\text { the Holy Sepulchre is signed on } 22 \text { March } 2016 \text { to rehabilitate the Holy Aedicule. Based } \\
\text { on the results of the study and the rehabilitation interventions proposed, a } \\
\text { rehabilitation project was initiated, supervised by NTUA. The rehabilitation project } \\
\text { was successfully implemented and completed in March } 2017 \text { [62-67]. }\end{array}$ \\
\hline
\end{tabular}

The rehabilitation project implemented under the scientific supervision of the National Technical University of Athens (NTUA), provided the framework to examine the building and decorative materials of the Holy Aedicule. It should be highlighted that on the 26th of October, 2016, the NTUA team was granted permission by the three Christian Communities-Guardians of the Holy Tomb, to open the Tomb of Christ during the grouting of the structure, in order to protect the burial surface. The top marble slab was thus shifted and the interior of the burial monument came to light; a lower marble plate, fragmented in a direction from west to east and in position to the north of the Tomb, was revealed; on the southern part of the Tomb, the burial rock, the original burial surface of the Tomb, was revealed $[62,68]$.

The current study will try to identify the provenance of marble samples collected from the most holy site of Christianity, the Tomb of Christ, as well as from various locations of the Holy Aedicule enclosing it, by using mineralogical, petrographic and C-O isotopic analyses. The combination of these methods enables the marbles to be identified with an acceptable degree of reliability [3]. The obtained results are compared to relevant literature data in order to establish their provenance and an attempt for an intra-site topographical discrimination is made. These results are discussed in relation to historical sources and testimonies, as well as to previously published archaeometric results regarding the historical mortars of the Holy Aedicule [69]. Thus, new data regarding the evolution of the Aedicule, as well as information regarding the selection of marbles throughout the monument's history, emerges. 


\section{Materials and Methods}

\subsection{Sampling}

Marble samples were collected from the interior facings of the Holy Aedicule (Chapel of the Angel and Holy Tomb Chamber), as well as from the marble slabs enclosing the Tomb of Christ. Six marble samples were studied: four from the Holy Tomb Chamber and two from the Chapel of the Angel. In particular, in the Holy Tomb Chamber, one sample was taken from the marble facing of the interior south wall opposite the Tomb, while the other three were collected from the Holy Tomb cladding: one from the upper marble plate, worshipped today, one from the interior marble plate, which was revealed during the NTUA rehabilitation project, and one from a marble fragment found within the Tomb. Two marble samples were collected from the western wall of the Chapel of the Angel, northern and southern to the low entrance of the Holy Tomb Chamber, respectively.

A summarized description of the marble samples under investigation and their sampling location is presented in Table 2. Sampling locations on the ground plan of the Holy Aedicule are presented in Figure 5, while in Figures 6-9, views of the sampling areas are displayed.

Table 2. Codes, short description of the sampling locations and macroscopic features of the studied samples.

\begin{tabular}{|c|c|c|}
\hline Sample Code & $\begin{array}{l}\text { Brief Description of the } \\
\text { Sampling Location }\end{array}$ & $\begin{array}{c}\text { Macroscopic Features on } \\
\text { Fragmented (Natural) Surface }\end{array}$ \\
\hline OM-10 & $\begin{array}{l}\text { Tomb Chamber, North side, Holy Tomb } \\
\text { interior, grey marble plate above the } \\
\text { burial bed rock and under the amber } \\
\text { hued* marble plate. See Point } 1 \text { at }^{*} \text { Figures } 5 \text { and } 6 .\end{array}$ & $\begin{array}{l}\text { White, medium to coarse grained, } \\
\text { gray in parallel bands }\end{array}$ \\
\hline OM-11 & $\begin{array}{c}\text { Tomb Chamber, North side, Holy Tomb } \\
\text { exterior, amber hued marble plate. See } \\
\text { Point } 3 \text { at Figures } 5 \text { and } 6 .\end{array}$ & White, medium to coarse grained \\
\hline OM-13 & $\begin{array}{c}\text { Tomb Chamber, South side, smooth } \\
\text { surface of interior marble facing, } \\
\text { opposite the Holy Tomb. See Point } 4 \text { at } \\
\text { Figures } 5 \text { and } 8 .\end{array}$ & White, medium to coarse grained \\
\hline OM-49 & $\begin{array}{l}\text { Tomb Chamber, North side, Holy Tomb } \\
\text { interior, marble fragment, found in the } \\
\text { filling material of the Holy Tomb. See } \\
\text { Point } 2 \text { at Figures } 5 \text { and } 6 .\end{array}$ & $\begin{array}{l}\text { White, medium to coarse grained, } \\
\text { gray in parallel bands }\end{array}$ \\
\hline OM-50 & $\begin{array}{l}\text { Chapel of the Angel, North-West side, } \\
\text { northern to the Entrance of the Tomb } \\
\text { Chamber, relief of interior marble facing. } \\
\text { See Point } 5 \text { at Figures } 5 \text { and } 9 .\end{array}$ & White, medium to coarse grained \\
\hline OM-51 & $\begin{array}{l}\text { Chapel of the Angel, South-West side, } \\
\text { southern to the Entrance of the Tomb } \\
\text { Chamber, smooth surface of interior } \\
\text { marble pilaster. See Point } 6 \text { at } \\
\text { Figures } 5 \text { and } 9 .\end{array}$ & White, coarse grained \\
\hline
\end{tabular}

\footnotetext{
* The amber hued coloration is noticed on the external surface of the marble plate and it is attributed to the application of myrrh for centuries as part of the liturgical functions.
} 


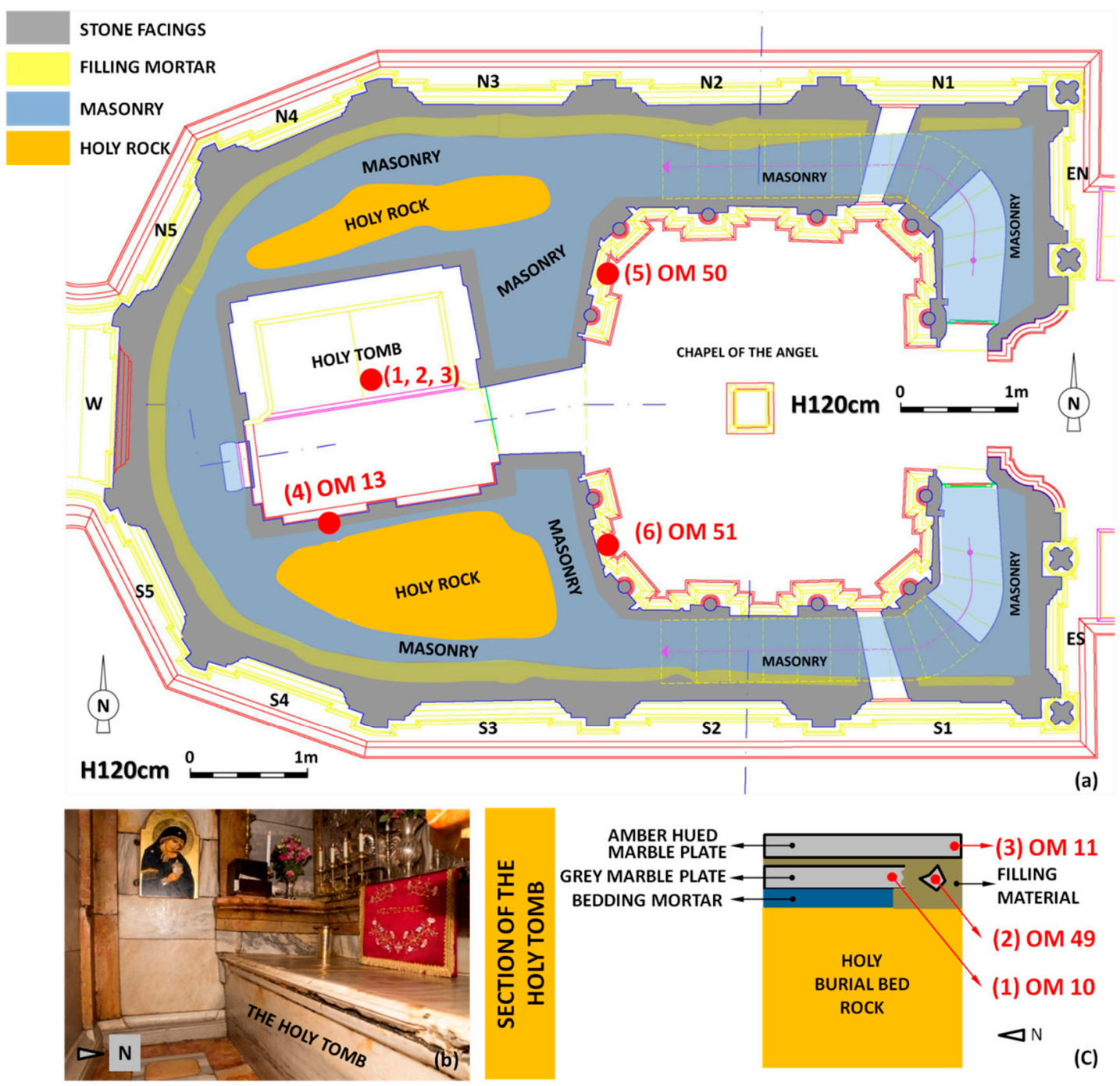

Figure 5. (a) Depiction of sampling locations on ground plan of the Holy Aedicule (ground plan modified from Lampropoulos et al 2017 [70]); (b) View of the Holy Tomb from the entrance on the east; (c) Schematic representation of the Holy Tomb: section depicting the layering of materials and the sampling areas of OM11, OM49, OM10. 

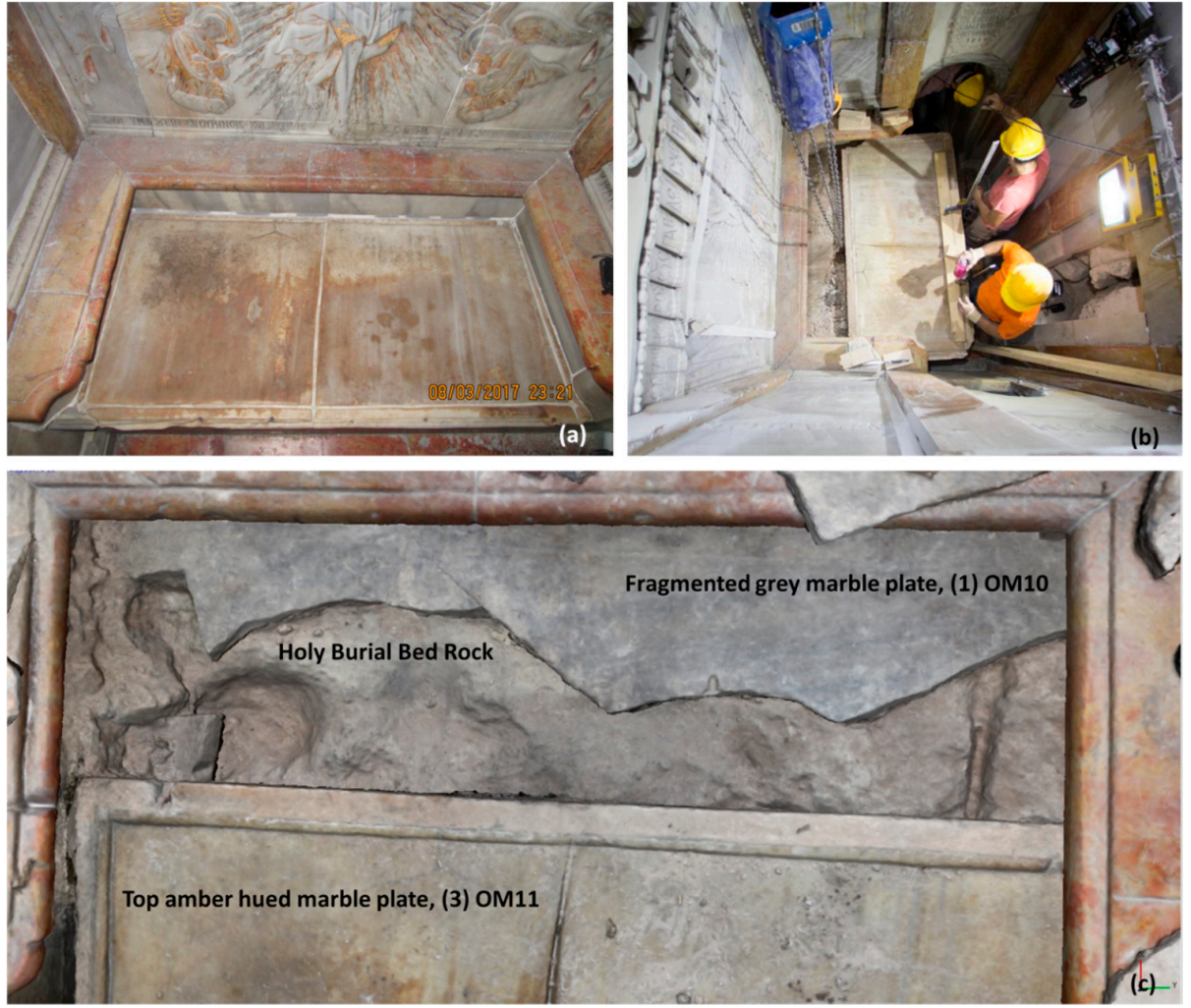

Figure 6. Description of sampling areas of marble samples (1) OM10 and (3) OM11: (a) the Holy Tomb with the top amber hued marble plate, that it is worshiped today, in place; (b) View of the Holy Tomb during the shifting out of position of the top amber hued marble plate on October 26, 2016; (c) The open Holy Tomb where it was visible: the Holy Burial Bed Rock; the fragmented gray marble plate (sampling area of (1) OM10); the, shifted out of position, top amber hued marble plate (sampling area of (3) OM11).
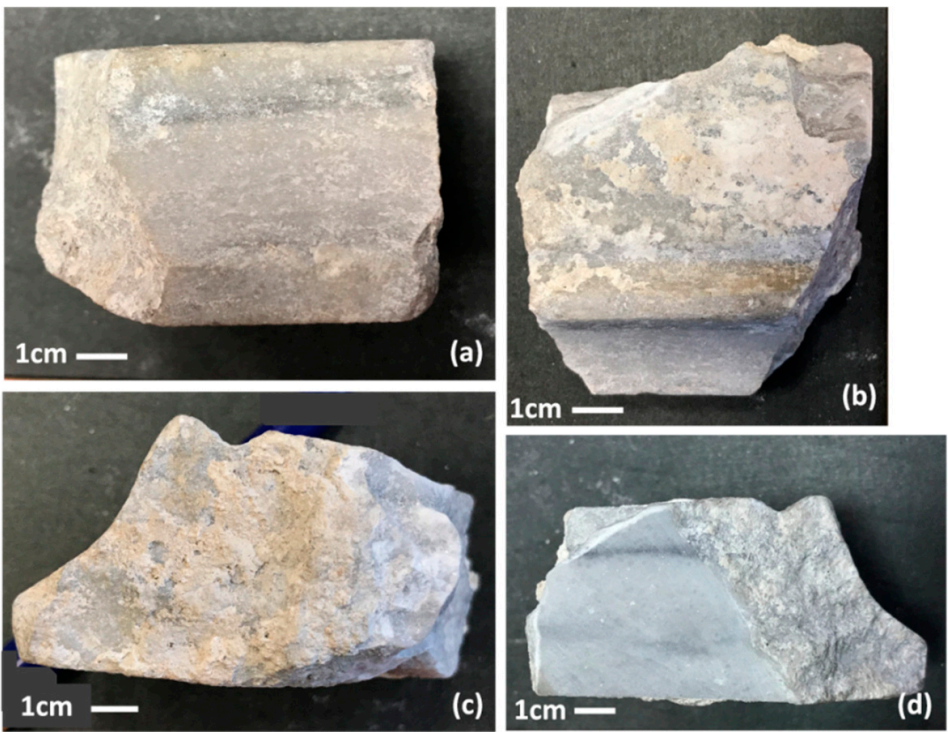

Figure 7. Sample (2) OM49: the marble fragment, found within the Holy Tomb; (a) front view, where characteristic grey stripes can be macroscopically observed; (b) top view, where mortar residues are evident; (c) side view, where mortar residues and a special curved ending are evident; (d) the other side view, where, besides the special curved ending, characteristic grey stripes can be macroscopically observed. 


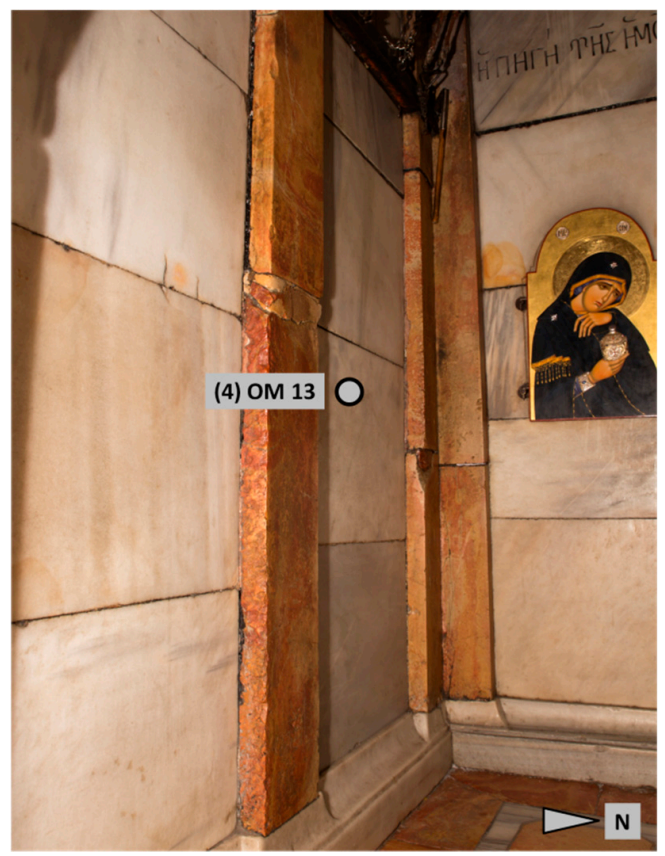

Figure 8. Description of sampling area of marble sample (4) OM13: smooth interior marble facing, opposite the Holy Tomb in the Holy Tomb Chamber.

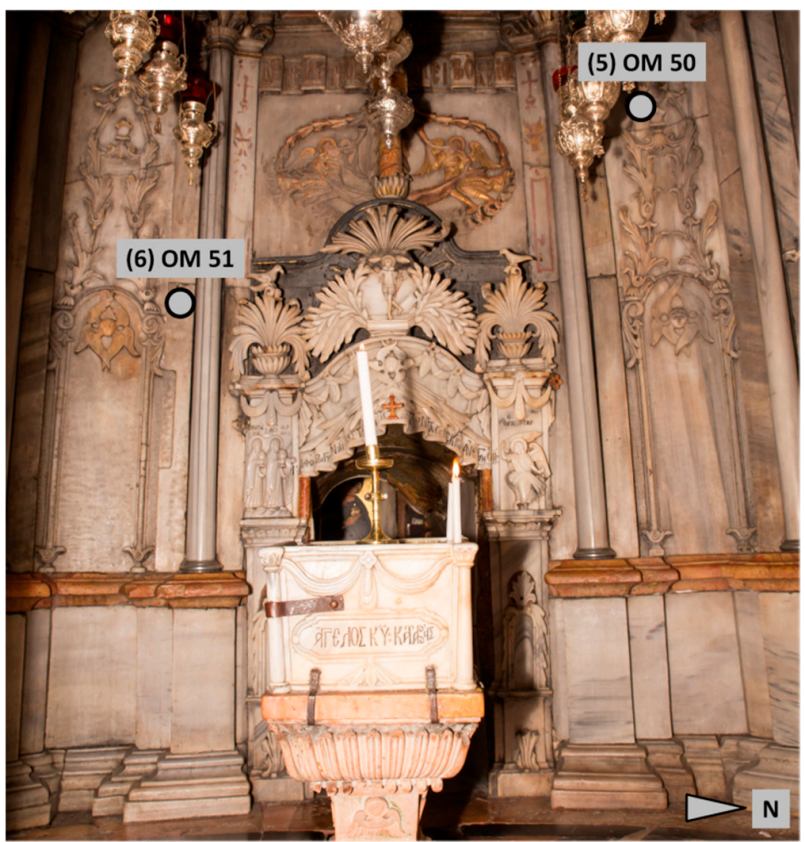

Figure 9. Description of sampling areas of marble samples (5) OM50 and (6) OM51 in the Chapel of the Angel; At the right hand side-northern to the Tomb Chamber entrance, the sampling area of sample (5) OM50, is displayed; At the left hand side-southern to the Tomb Chamber entrance, the sampling area of sample (6) OM51, is displayed.

\subsection{Analytical Techniques}

From the six (6) marble samples that were collected, thin-and-polished sections were created and underwent detailed petrographic investigation. The technique of optical microscopy was performed using a Leica DM2500P optical microscope mounted with a Nikon camera. MGS values were measured on images collected through a ProgRes-C14PLUS video-camera, using the ProgRes CapturePRO2.1 software. 
Stable isotope $(C, O)$ analyses of the studied marble samples were performed; marble chips, hand-picked for every sample under the stereoscope in order to avoid any contaminations of the samples (e.g., from mortar rests), were pulverized in an agate mill for this purpose. The marble powders were reacted with $100 \%$ phosphoric acid at $70^{\circ} \mathrm{C}$ using a Gasbench II connected to a ThermoFisher Delta V Plus Mass spectrometer. All values are reported in per mil relative to V-PDB (Vienna Pee Dee Belemnite). Reproducibility and accuracy were monitored by replicate analysis of laboratory standards calibrated by assigning $\delta^{13} \mathrm{C}$ values of $+1.95 \%$ o to NBS19 and $-47.3 \%$ o to IAEA-CO9 and $\delta^{18} \mathrm{O}$ values of $-2.20 \%$ o to NBS19 and $-23.2 \%$ o to NBS18. Reproducibility for $\delta^{13} \mathrm{C}$ and $\delta^{18} \mathrm{O}$ was \pm 0.01 and \pm 0.08 , respectively.

\section{Results}

\subsection{Petrographic Characterization of the Studied Samples}

The studied samples were taken from an archaeological monument of great significance, thus each one will be described separately in the present section. Panoramic microphotographs, taken under crossed-polarized light are presented in Figure 10. Detailed textural and petrographic characteristics for each sample are depicted in Figures 11-16.
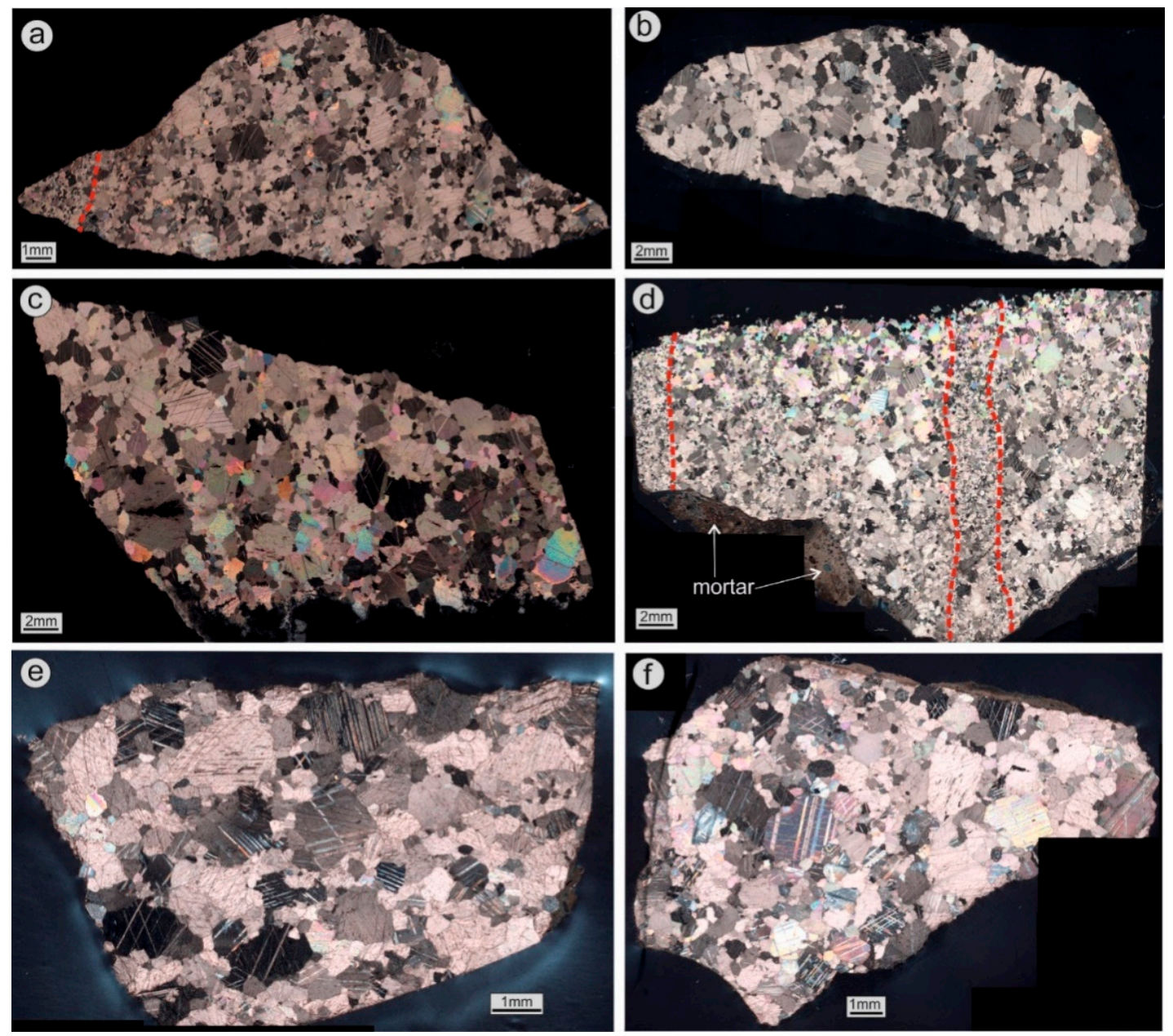

Figure 10. Transmitted light, panoramic microphotographs of the studied samples, taken under crossed-polarized light: (a) Sample OM10; (b) sample OM11, (c) sample OM13; (d) sample OM49, note the mortar rest on the right corner of the sample; (e) sample OM 50; (f) sample OM51. Note the characteristic heteroblastic fabric on all samples (mortar-type). Red dotted lines mark the areas that belong to grey-colored bands in samples OM10 and OM49. 
A common characteristic of all six samples is that they emit an intense smell of sulfur upon scraping or hitting, fact that implies an organic component (bituminous compounds). Coloration of the studied samples is relatively homogeneous, around 180-200. Two of the samples (OM10 and OM49) are characterized by a relatively small number of parallel and mm-sized grayish bands that can be observed even in macroscopic scale. In microscopic scale, these bands are composed of fine-grained calcite, indication that the rock has suffered an extent of tectonic deformation. What is also common in all the studied samples is their characteristic heteroblastic fabric, known as "mortar-type". This fabric is characterized by two groups of crystal sizes: the first largest group comprises subhedral calcite porphyroblasts, which maximum grain size (MGS) ranging from 1.6 up to $\sim 3 \mathrm{~mm}$ (most common values are $>2 \mathrm{~mm}$ ). This fact is helpful to characterize the studied samples as medium/coarse grained marbles, as the value of $2 \mathrm{~mm}$ is commonly used in archaeometry as a cutoff between the fine- and medium/coarse-grained marble varieties [3]. The second group is characterized by much smaller MGS (less than $1 \mathrm{~mm}$ ). These grain sizes are detected in the Holy Aedicule samples under examination, in the grey-colored bands of samples OM10 and OM49, as well as in calcite crystals that form around the porphyroblasts, due to strain deformation and subsequent neocrystallization. Deformation of the rocks is also evidenced by bent twinning lines in calcite crystals. Accessory minerals in all samples include mainly mica (phlogopite), while minor apatite and pyrite were also observed. Dolomite was also identified, but its volumetric participation in the rocks is rather insignificant.
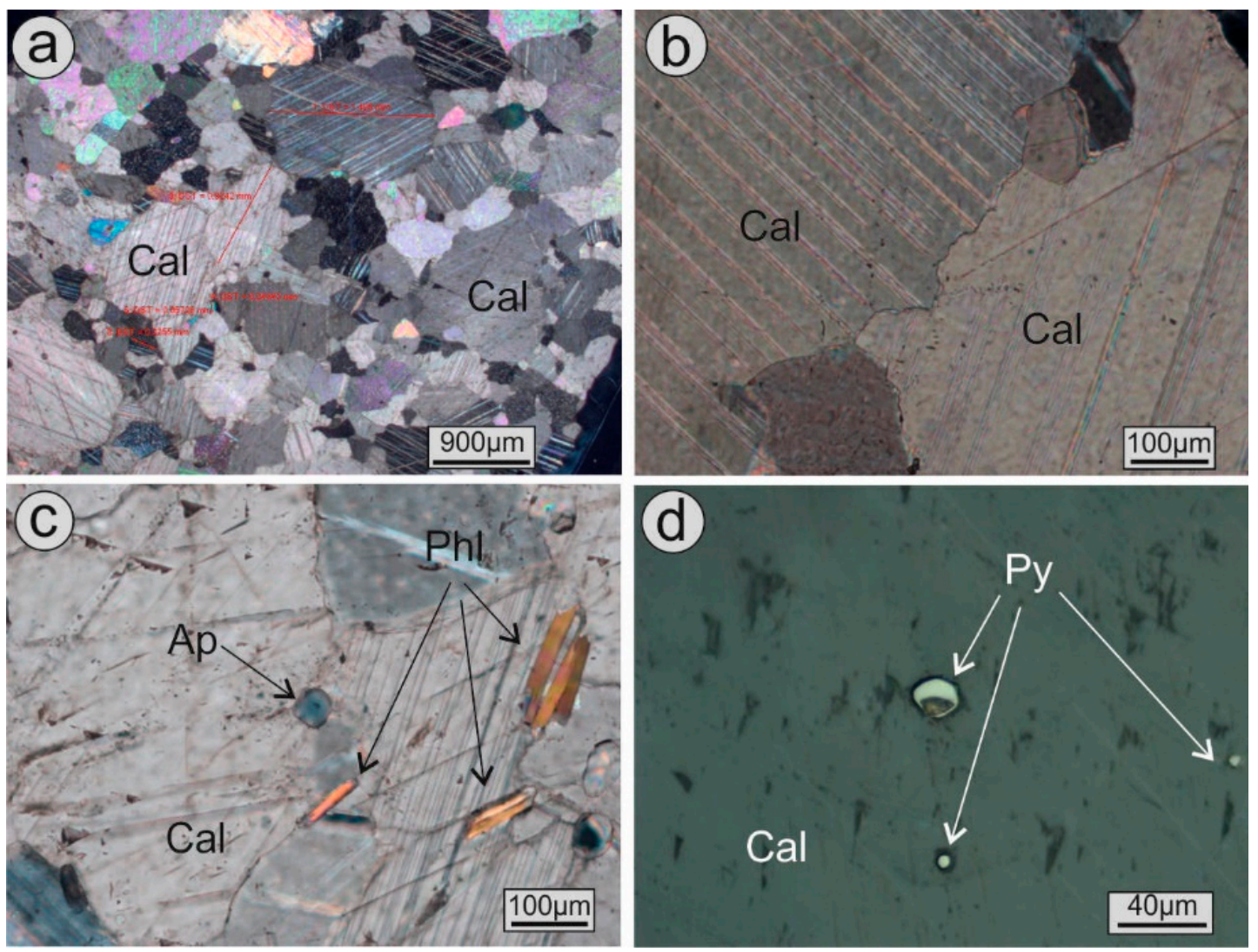

Figure 11. Transmitted (a-c) and reflected (d) light microphotographs of sample OM10: (a) Heteroblastic fabric ("mortar"), crossed-polarized light; (b) sutured and partly embayed grain boundaries, crossed-polarized light; (c) anhedral apatite (Ap) crystal included, along with phlogopite (Phl) in calcite (Cal), plane-polarized light; (d) round-shaped pyrite (Py) crystals included in calcite (Cal).

\subsubsection{Sample OM10}

Calcite is the dominant mineral component of the sample. Dolomite is present in minor amounts. The fabric is strongly heteroblastic, ("mortar-type", Figure 11a). Tectonic deformation is 
expressed by the presence of mm-sized bands, which are macroscopically observed as grey-colored stripes. They are composed of fine-grained calcite, along with parallel-oriented, mica-group minerals (phlogopite/muscovite). MGS values reach up to $2.0 \mathrm{~mm}$ for the coarse grain parts and are significantly lower, up to $0.4 \mathrm{~mm}$, in the fine-grained bands. Xenomorphic crystals of calcite in the groundmass often exhibit polysynthetic twinning, as a result of deformation. Grain boundary shapes are typically sutured, in some cases embayments were also identified (Figure 11b). Accessory minerals are commonly phlogopite, rarely apatite and pyrite (Figure 11c,d).

\subsubsection{Sample OM11}

Calcite is the dominant mineral component of the sample and forms subhedral porphyroblastic crystals (MGS $1.7 \mathrm{~mm}$ ) surrounded by smaller neoblasts (Figure 12a). The fabric is strongly heteroblastic, (mortar-type, Figure 12a) and many crystals display intense polysynthetic twinning. In some cases, twinning lines are bent, a fact that indicates tectonic deformation. Calcite grains usually display sutured boundaries, but in places embayed boundaries were also observed (Figure 12b,c) Phlogopite, apatite and pyrite, which forms round-shaped grains, were identified as accessory phases (Figure 12b-d).
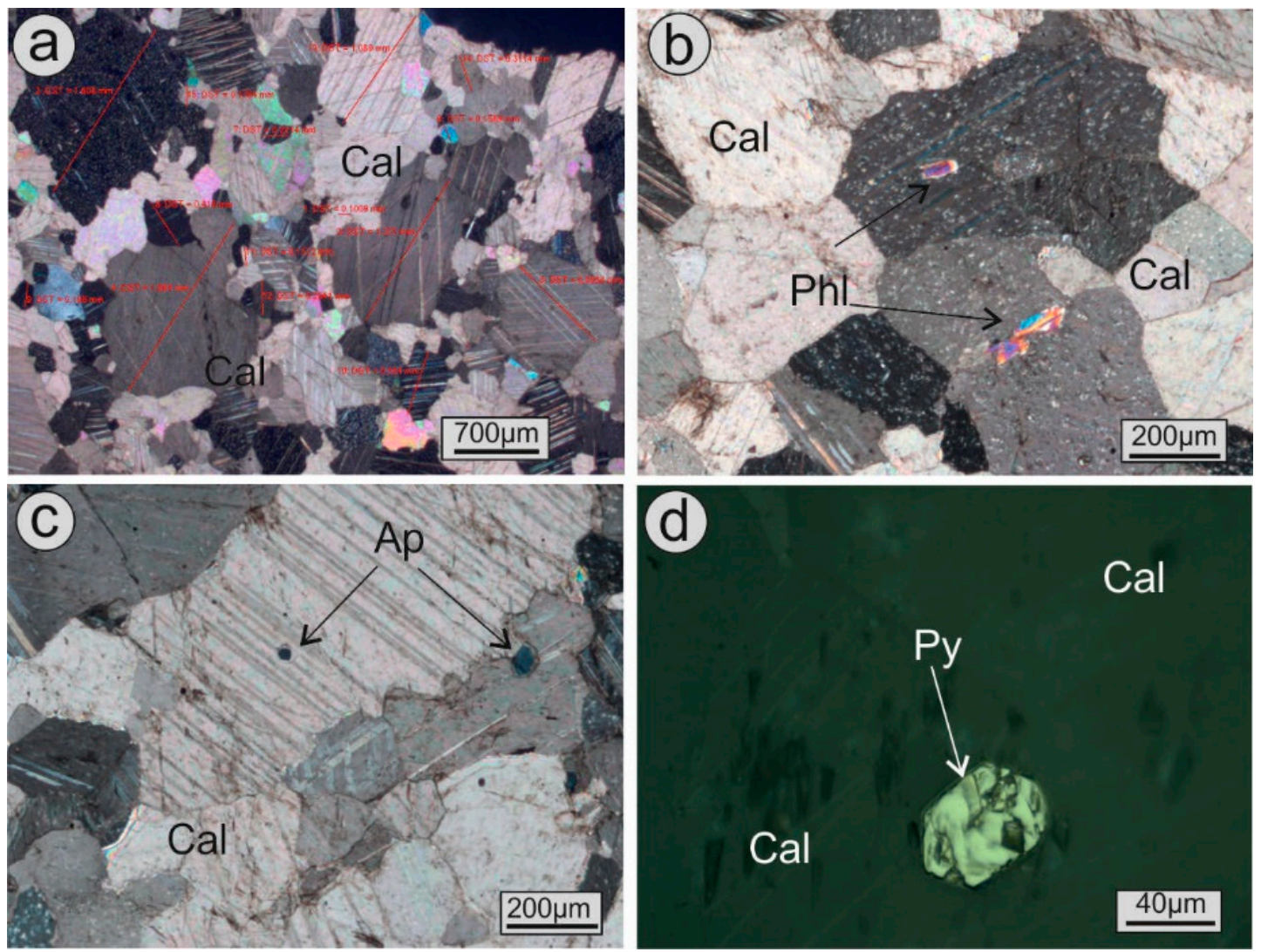

Figure 12. Transmitted $(\mathbf{a}-\mathbf{c})$ and reflected (d) light microphotographs of sample OM11: (a) Heteroblastic fabric ("mortar"), crossed-polarized light; (b) sutured calcite (Cal) grain boundaries. At places calcite includes phlogopite (Phl), crossed-polarized light; (c) anhedral apatite (Ap) crystal included in calcite (Cal). Note the sutured and partly embayed grain boundaries, crossed-polarized light; (d) round-shaped pyrite (Py) crystal included in calcite (Cal).

\subsubsection{Sample OM13}

Calcite is the dominant mineral component of the sample. Dolomite is present in minor amounts. The sample exhibits a heteroblastic fabric ("mortar-type", Figure 13a,c), with maximum grain sizes being slightly smaller compared to the other samples, around $1.6 \mathrm{~mm}$. Deformation is also remarked in this sample, as xenomorphic crystals of calcite in the groundmass often exhibit polysynthetic twinning. 
Rarely, triple point junctions of calcite grains (Figure 13b) were observed. Micas (phlogopite muscovite), anhedral apatite and round-shaped pyrite were identified as main accessory phases (Figure 13c,d).
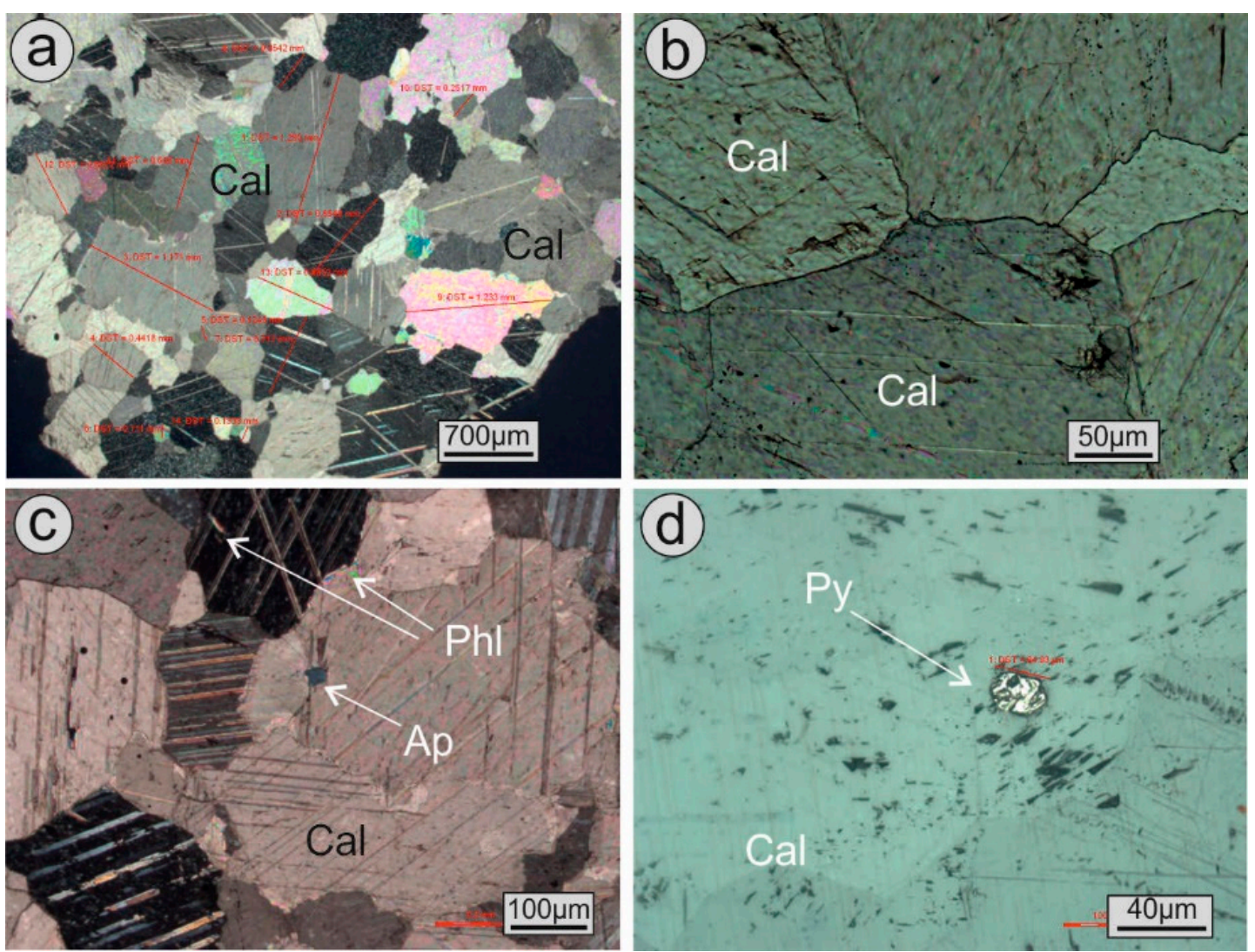

Figure 13. Transmitted $(\mathbf{a}-\mathbf{c})$ and reflected (d) light microphotographs of sample OM13: (a) Heteroblastic fabric ("mortar"), crossed polarized light; (b) slightly sutured calcite (Cal) grains forming triple-point junctions, plane-polarized light; (c) anhedral apatite (Ap) crystal included in calcite (Cal). At places calcite includes phlogopite (Phl). Note the sutured and partly embayed grain boudaries; (d) round-shaped pyrite (Py) crystal included in calcite (Cal).

\subsubsection{Sample OM49}

This sample is characterized by heteroblastic fabric (Figure 14a) and the presence of a fine-grained band, with a maximum thickness of about $500 \mu \mathrm{m}$ (Figure 14b). This band, which is also remarked as a grey-colored stripe in macroscopic scale, is composed of anhedral calcite with maximum MGS up to 0.6 $\mathrm{mm}$. These MGS values are much smaller compared to the MGS values of calcite grains in the rest of the rock, where they reach up to almost $2 \mathrm{~mm}$. Bent twinning lines are common, along the band and the rest of the rock as well. Grain boundaries inside the band are commonly embayed, while in the rest of the sample, the most common grain boundary shape is sutured, although embayments were observed here as well. Minor mineralogical components like apatite and micas (phlogopite and/or muscovite) were identified (Figure 14c), with the latter being commonly found in the band, oriented parallel to its major dimension. Rarely, round-shaped pyrite was observed included in calcite (Figure 14d). 

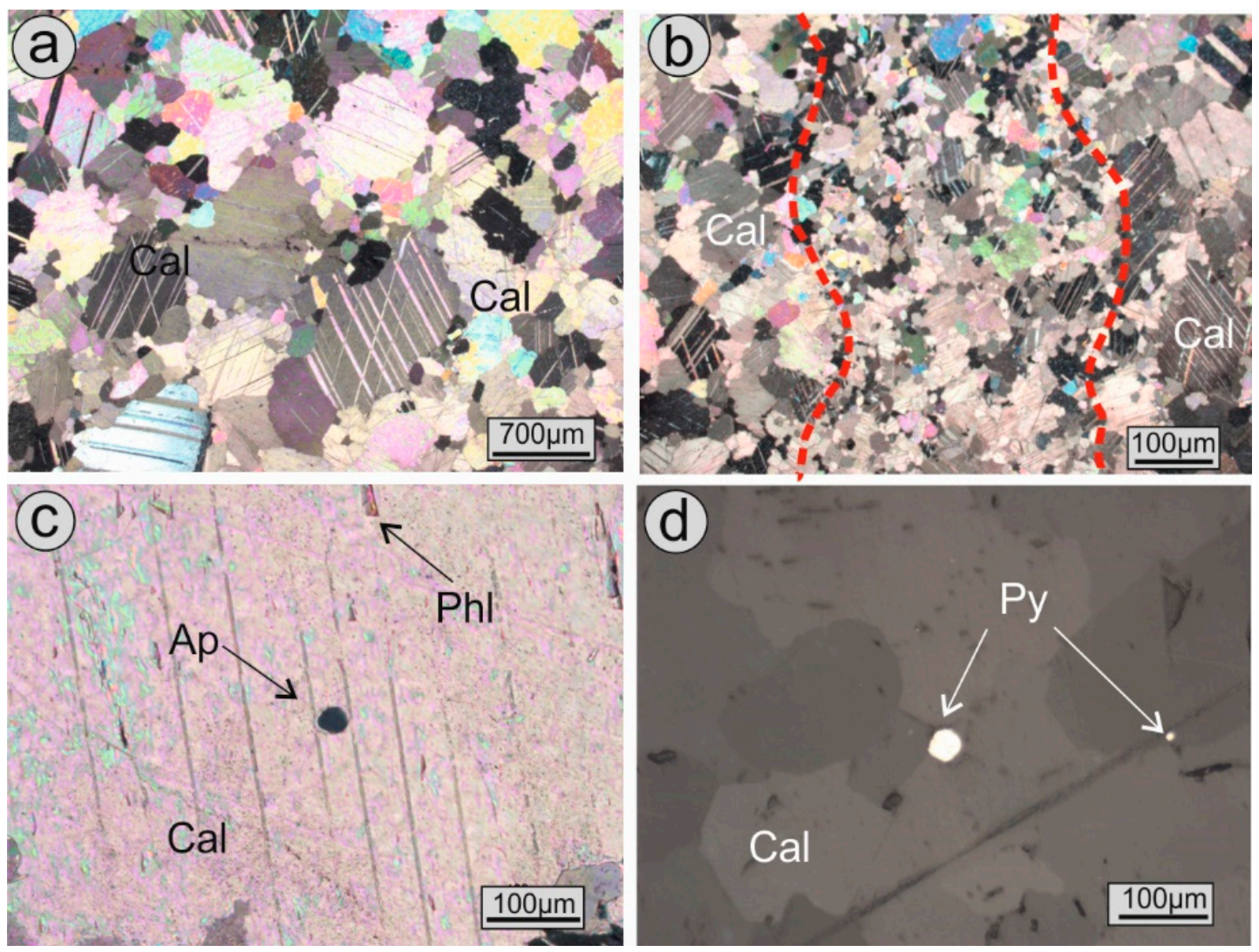

Figure 14. Transmitted (a-c) and reflected (d) light microphotographs of sample OM49: (a) heteroblastic fabric ("mortar") in calcite grains (Cal) most of which exhibit polysynthetic twinning, crossed-polarized light; (b) fine-grained calcite (Cal) crystals composing a band, which is grey-colored in macroscopic scale, crossed-polarized light; (c) anhedral apatite (Ap) crystal included in calcite (Cal), crossed-polarized light; (d) round-shaped pyrite (Py) crystals included in calcite (Cal).

\subsubsection{Sample OM50}

This sample exhibits a characteristic heteroblastic fabric ("mortar-type", Figure 15a). Calcite is the predominant mineralogical constituent. Grain boundaries are usually sutured, but in rare cases, straight-sided grain boundaries, leading to the formation of triple point junctions $\left(120^{\circ}\right)$ were observed (Figure 15b), perhaps suggesting local equilibrium conditions. Deformation is also traced in this sample, as xenomorphic crystals of calcite in the groundmass often exhibit polysynthetic twinning. Maximum grain sizes in this sample reach up to $1.7 \mathrm{~mm}$. Anhedral apatite and round-shaped pyrite were identified as main accessory phases, while mica group minerals are quite rare. Apatite forms anhedral to subhedral rains, and its size does not exceed $100 \mu \mathrm{m}$ (Figure 15c). Pyrite forms, fine-grained (up to $20 \mu \mathrm{m}$ ) rounded crystals, scattered in calcite. 

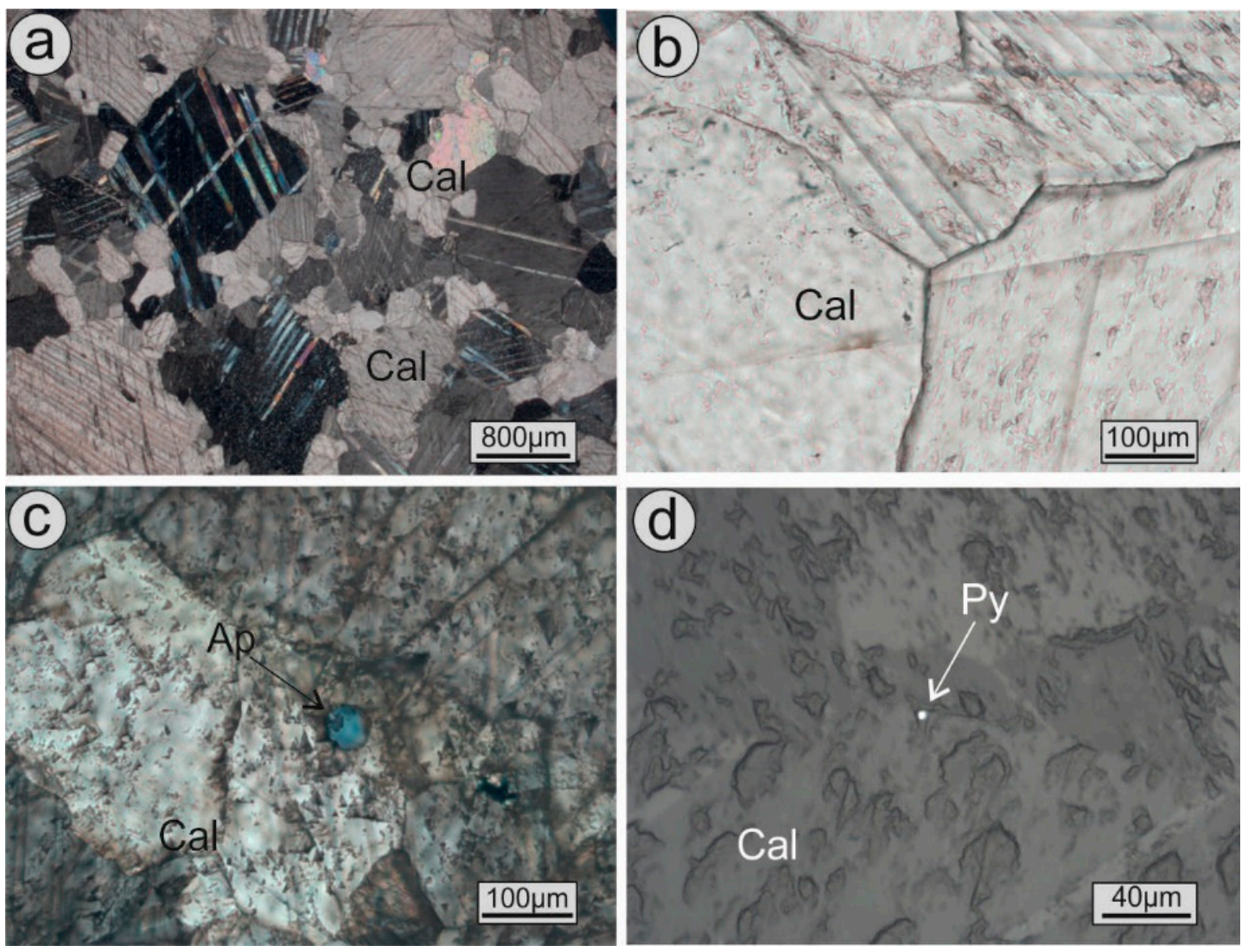

Figure 15. Transmitted (a-c) and reflected (d) light microphotographs of sample OM50: (a) heteroblastic fabric ("mortar") in calcite grains (Cal) most of which exhibit polysynthetic twinning, crossed-polarized light; (b) calcite (Cal) crystals forming a triple-junction and exhibiting slightly sutured grain boundaries, crossed-polarized light; (c) anhedral apatite (Ap) crystal included in calcite (Cal), plane-polarized light; (d) round-shaped pyrite (Py) crystal included in calcite (Cal).

\subsubsection{Sample OM51}

The sample is characterized by anhedral calcite grains that compose a heteroblastic fabric ("mortar" type, Figure 16a). The majority of these crystals are characterized by sutured and minor embayed grain boundaries (Figure 16b). Maximum grain size reaches up to $2.3 \mathrm{~mm}$. Bent twinning lines in calcite crystals are common, indicating tectonic deformation. Accessory phases include minor dolomite, mica group minerals (phlogopite/muscovite), apatite and pyrite (Figure 16c,d) which forms round-shaped grains included in calcite. 

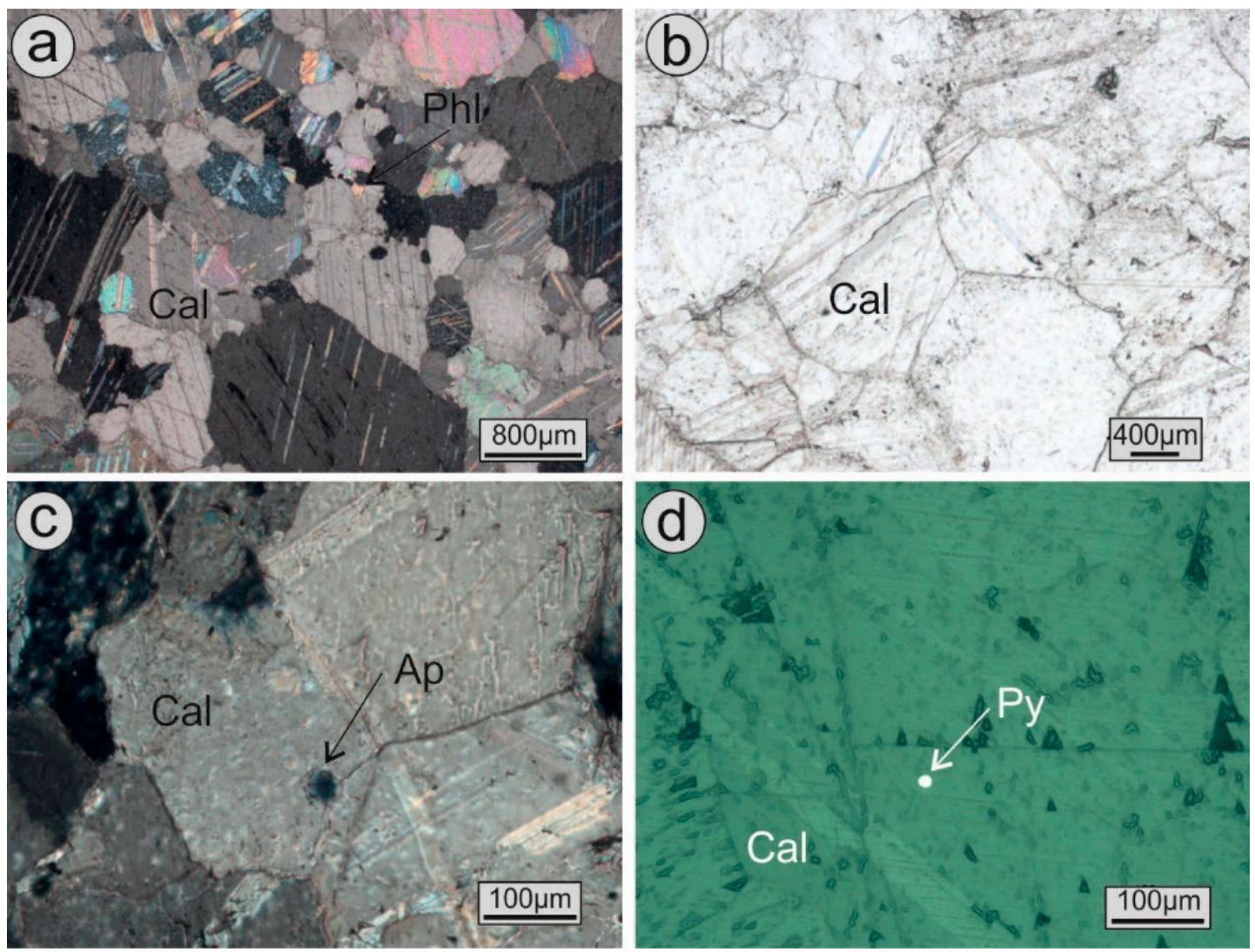

Figure 16. Transmitted (a-c) and reflected (d) light microphotographs of sample OM51: (a) heteroblastic fabric ("mortar") in calcite grains (Cal) most of which exhibit polysynthetic twinning. Minor phlogopite (Phl) is also present, crossed-polarized light; (b) calcite (Cal) crystals with partly sutured and embayed grain boundaries, plane-polarized light; (c) anhedral apatite (Ap) crystal included in calcite (Cal), crossed-polarized light; (d) round-shaped pyrite (Py) crystal included in calcite (Cal).

The above described microscopy results are summarized in Table 3, where the mineralogical content, the fabric, as well as the MGS and GBS parameters are stated.

Table 3. Petrographic features and mineralogical content of the studied samples.

\begin{tabular}{|c|c|c|c|c|}
\hline Sample & Mineralogy & Fabric & MGS & GBS \\
\hline \multirow{2}{*}{ OM-10 } & \multirow{2}{*}{$\mathrm{Cal}( \pm \mathrm{Dol}) \pm \mathrm{Phl} \pm \mathrm{Ap} \pm \mathrm{Py}$} & \multirow{2}{*}{$\mathrm{HE}$} & 2.0 & \multirow{2}{*}{ Sutured, embayed } \\
\hline & & & $0.4^{*}$ & \\
\hline OM-11 & $\mathrm{Cal}( \pm \mathrm{Dol}) \pm \mathrm{Phl} \pm \mathrm{Ap} \pm \mathrm{Py}$ & $\mathrm{HE}$ & 1.7 & Sutured, embayed \\
\hline OM-13 & $\mathrm{Cal}( \pm \mathrm{Dol}) \pm \mathrm{Phl} \pm \mathrm{Ap} \pm \mathrm{Py}$ & $\mathrm{HE}$ & 1.6 & Sutured, embayed \\
\hline \multirow{2}{*}{ OM-49 } & \multirow{2}{*}{$\mathrm{Cal}( \pm \mathrm{Dol}) \pm \mathrm{Phl} \pm \mathrm{Ap} \pm \mathrm{Py}$} & \multirow{2}{*}{$\mathrm{HE}$} & 1.9 & \multirow{2}{*}{ Sutured, embayed } \\
\hline & & & $0.6^{*}$ & \\
\hline OM-50 & $\mathrm{Cal}( \pm \mathrm{Dol}) \pm \mathrm{Phl} \pm \mathrm{Ap} \pm \mathrm{Py}$ & $\mathrm{HE}$ & 1.7 & Sutured, embayed \\
\hline OM-51 & $\mathrm{Cal}( \pm \mathrm{Dol}) \pm \mathrm{Phl} \pm \mathrm{Ap} \pm \mathrm{Py}$ & $\mathrm{HE}$ & 2.3 & Sutured, embayed \\
\hline
\end{tabular}

Abbreviations: $\mathrm{Cal}=$ calcite; $\mathrm{Dol}=$ dolomite; $\mathrm{Phl}=$ phlogopite; $\mathrm{Ap}=$ apatite; $\mathrm{Py}=$ pyrite, $\mathrm{HE}=$ heteroblastic; MGS $=$ maximum grain size in $\mathrm{mm}$; GBS $=$ grain boundary shape. Maximum grain size (MGS). Values with $\left(^{*}\right)$ refer to calcite grains from grey-colored bands. 


\subsection{Isotopic Signature of the Studied Samples}

Isotopic values of the six samples can be generally characterized as homogeneous, despite the observed variation in their $\delta^{13} \mathrm{C}$ and $\delta^{18} \mathrm{O}$ val ues and are summarized in Table 4.

$\delta^{18} \mathrm{O}$ values are negative in all samples and range from -2.49 to -1.13 . The majority of the samples (OM10, OM13, OM49 and OM50) display very homogeneous $\delta^{18} \mathrm{O}$ values (ranging from -1.89 to $-1.13 \%$ o-PDB), while the rest two samples (OM11 and OM51) are isotopically lighter, with values -2.49 and $-2.06 \%$ o V-PDB respectively. Regarding the $\delta^{13} \mathrm{C}$ values, they vary slightly from 2.43 to $3.37 \%$ o V-PDB.

Values of the studied samples are plotted in the marble isotopic reference diagram (Figure 17, after Gorgoni et al. 2002 [18]). In this diagram, isotopic fields of white marbles that were commonly used in antiquity have been marked, based on published isotopic data for marbles from Carrara (Italy), Penteli, Naxos, Paros, Thassos (Greece) and Afyon, Aydin, Proconnesos (Turkey). Samples from this study plot in the central part of the Proconnesos-1 marble field. Overlapping in this area is noticed with parts of other fields, which represent marbles from other localities. In particular, some samples plot along or inside the subfields for Thasos (subfields T1,2,3), Paros (subfields Pa2,3) and Carrara (field C).

Table 4. $\delta^{18} \mathrm{O}$ and $\delta^{13} \mathrm{C}$ values (\%o V-PDB) of the studied samples.

\begin{tabular}{ccc}
\hline Sample & $\boldsymbol{\delta}^{\mathbf{1 8}} \mathbf{O}$ & $\boldsymbol{\delta}^{\mathbf{1 3}} \mathbf{C}$ \\
\hline OM-10 & -1.89 & 3.08 \\
OM-11 & -2.49 & 2.59 \\
OM-13 & -1.58 & 3.37 \\
OM-49 & -1.58 & 3.31 \\
OM-50 & -1.13 & 2.43 \\
OM-51 & -2.06 & 2.71 \\
\hline
\end{tabular}

V-PDB: Vienna Pee Dee Belemnite.

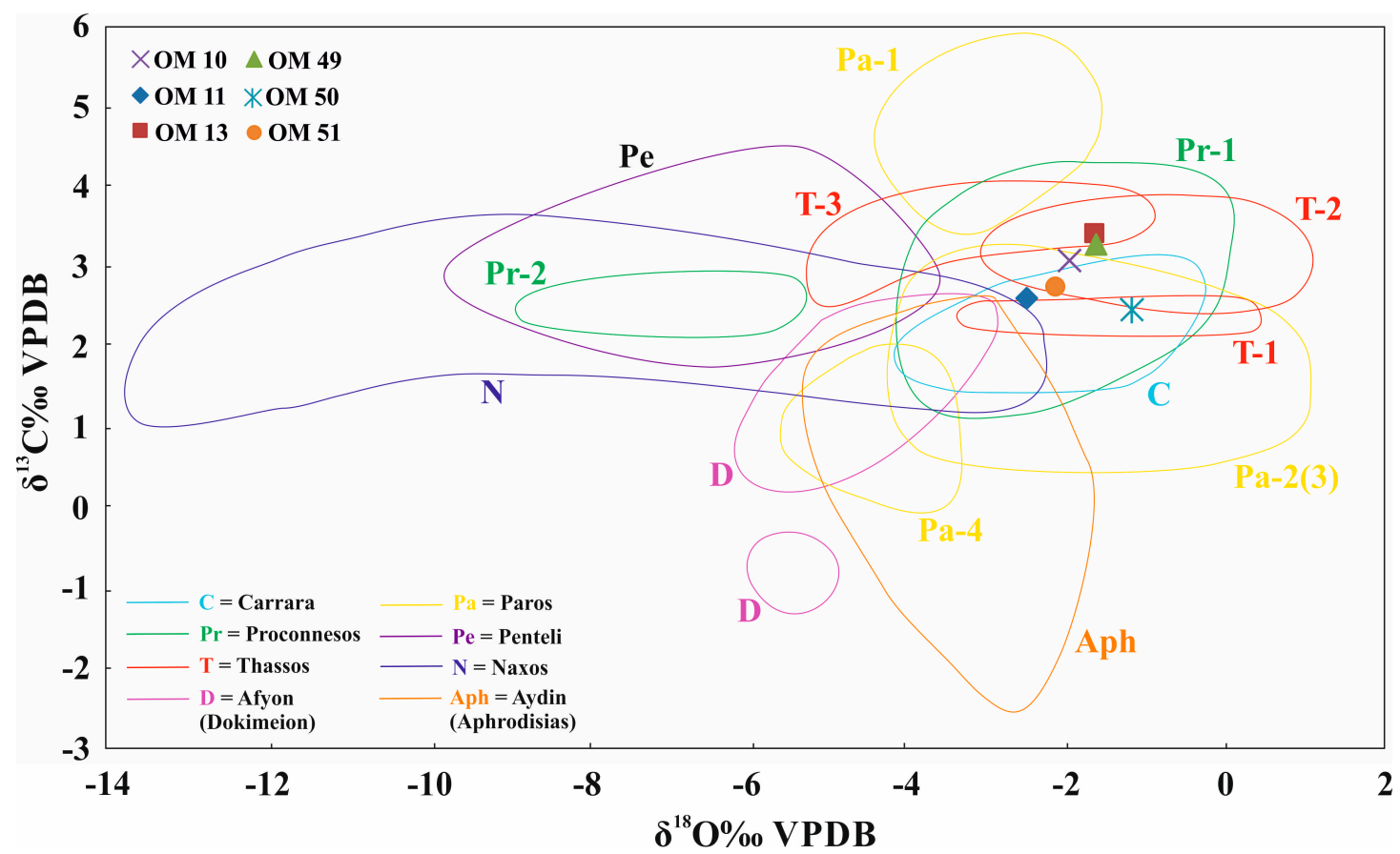

Figure 17. $\delta^{18} \mathrm{O}$ versus $\delta^{13} \mathrm{C}$ plot, displaying the isotopic values of the studied samples. Fields of ancient quarrying samples are from Gorgoni et al. 2002 [18]. Pr1,2 = Proconnesos, variety 1 and 2; T1,2 = Thasos-Alyki; T3 = Thasos-Vathy; $\mathrm{C}=$ Afyon (Dokimeion); Pa1 = Paros-Lychnites, $\mathrm{Pa} 2,3$ = Paros-Chorodaki, Pa4 = Paros-Lakkoi; Pe = Penteli; N = Naxos; Aph = Aydin. 


\section{Discussion}

Provenance of the numerous marble varieties that have been used in archaeological sites worldwide still remains one of the most debated topics [11]. This matter is of critical importance due to the need of determining a suitable source that can supply the optimum restoration material, in terms of physicochemical, mechanical and historical compatibility [2,3,12]. Furthermore, it can also reveal crucial information regarding the history of a monument and shed light on transportation routes and commercial practices. In this section, the results of the petrographic and isotopic characterization of the examined samples will be used to establish the provenance of the Holy Aedicule marbles and a discussion will be made in relation to possible intra-site discriminations and in relation to historical testimonies and evidence.

\subsection{Establishing the Provenance for the Holy Aedicule Marbles}

Based on the petrographic study results, all six samples display critical similarities-textural and mineralogical一that indicate a common origin.

The studied marble samples are characterized by explicit textural similarities: all six samples display a strong heteroblastic fabric, which is typical for marbles that have suffered a certain degree of deformation during (or after) peak of metamorphism. This fabric comprises xenomorphic calcite crystals that commonly form two distinct generations: the first refers to calcite porphyroblasts, which are scattered in a matrix of fine-grained calcite neoblasts, forming the second generation. This deformation-inferred fabric is not observed in marbles that have been formed under equilibrium conditions with no subsequent deformation, thus exhibiting isodiametric grains comprising the so-called homeoblastic fabric (e.g., the marbles from Carrara).

The studied samples exhibit a strong heteroblastic fabric, commonly described as "mortar-type", which is characterizing marbles originating from Proconnesos and is a strong vector towards provenance determination (Antonelli and Lazzarini 2015 [12] and references therein). Beyond the "mortar-type" fabric, all the studied samples carry more evidence of deformation, like the polysynthetic twinning, often with bent twinning lines, in the calcite grains. In addition, two of the samples, namely OM10 and OM49, exhibit another feature: they are characterized by grey-colored bands that can be observed with naked-eye as well. This feature gives the rock a relatively foliated texture, which is common to many marbles (e.g., those from Pentelikon mountain, Proconnesos etc. [12]). In the samples under investigation, these gray-colored bands are composed by preferentially oriented calcite grains and minor presence of accessory minerals, mainly micas (phlogopite and/or muscovite). Despite the strong deformation features that characterize the studied marble samples, local equilibrium conditions were also identified, as evidenced by the rare presence of straight-sided grains that conjunct into triple points.

The maximum grain size is a parameter that could also be used to identify the provenance of a marble sample, because along with textural features, it is related to the tectonometamorphic conditions of the rock. In terms of archaeometry, marbles are distinguished in three categories: fine-grained (MGS up to $2 \mathrm{~mm}$ ), average-medium grained (MGS 2-5 mm) and coarse-grained (MGS $>5 \mathrm{~mm}$ ). By using solely this parameter, and according to the coarse categorization proposed by Antonelli and Lazzarini 2015 [12], the studied samples, can be characterized as medium-grained, since they exhibit MGS that range mostly around $2 \mathrm{~mm}$. This category consists of marbles from Proconnesos, Aphrodisias (Aydin) and some Parian and Thassian varieties (Pa2,3,4 and T3 respectively). This parameter allows the exclusion of marble quarries that produce both fine- and coarse-grained marbles. Based on this ascertainment, marble producing areas that should not be considered as raw material sources for the Holy Aedicule marbles are: Penteli and Hymmetos, Paros 1/Lychnites, Carrara and Afyon (Dokimeion) which produce fine-grained varieties and Thasos 1-2 and Naxos, which produce very coarse-grained marble varieties. MGS identified in the present study, range from 1.6 to $2.3 \mathrm{~mm}$, gathered mostly around $2 \mathrm{~mm}$, and fit well in the published MGS range for all the medium-grained marble varieties (Proconnesos, Aphrodisias, Paros 2,3,4 and Thasos 3), thus suggesting that by defining this parameter only, no safe conclusions regarding provenance can be made. 
In parallel, accessory minerals have been also identified as possible key indicators useful in provenance determination [11]. The six studied samples contain the same accessory minerals paragenesis, which consist of (in decreasing volumetrically order) dolomite, mica (phlogopite, muscovite), apatite and pyrite. Mica group minerals, namely phlogopite and muscovite-paragonite-margarite (white micas, which are not easily distinguishable by optical microscopy only) are common accessory phases in many marbles (e.g., Proconnesos, Thassos, Paros, Naxos etc. [11]). The presence of apatite is also common in many marbles used in antiquity (e.g., Proconnesos, Carrara, Naxos, Thassos). Dolomite is present in marbles from a great number of different localities and so is pyrite. This fact precludes their use as provenance indicators.

By composing the above-mentioned data with the isotopic signature of the studied samples, their provenance should be searched between the Proconnesos, Thasos and Paros-3 marble quarries (see Figure 17), suggesting that a multi-parametric comparison of the studied samples to literature data for the above-mentioned localities is necessary.

Regarding the Thassian marble, despite its textural similarity to the studied samples, its heteroblastic texture is characterized as "mosaic-type" and not "mortar-type", as evident in the studied samples. Furthermore, the predominant grain boundary shape in Thassos marbles is the curved type, but in the samples from the Holy Aedicule, sutured and rarely embayed grain boundaries were the only identified types. The isotopic signature of the studied samples only partly (two out of six samples) overlaps the field of Thassos-3 (Vathy), indicating low isotopic relations. Finally, serpentine, which is common accessory mineral in the Thassian marbles (especially the dolomite-rich varieties), was not observed in any of the studied samples, and along with the previously-mentioned differences, Thassos should also be excluded as a possible source for the studied samples.

The Parian variety 3 (and 2), originating from the Chorodaki quarries, displays significant isotopic similarities to the studied samples, as four out of six, plot inside the relative subfield. Its MGS is also comparable to the observed MGS values. Textural and mineralogical variations though, are substantial to exclude this variety as well: the Parian marbles are characterized by mixed homeoblastic and heteroblastic, mosaic/lineated fabric, composed of curved and embayed crystals, and comprises accessory amphiboles, rutile, zircon \pm serpentine [11,12]. Beyond scarce grey-colored bands in the studied samples, which could be considered as a common feature of the studied samples to the Parian marble, the absence of accessory phases like amphibole, zircon and serpentine also enhance another sourcing locality rather than Paros.

Although a partial overlapping of three out of the six studied samples is noticed with the Carrara subfield in the isotopic diagram (Figure 17), this provenance has to be excluded. Carrara marbles present significantly lower MGS values and they are characterized as a fine-grained variety in contrast to the Holy Aedicule samples, which are classified as medium to coarse-grained marbles. Furthermore, no evidence of plagioclase crystals was found in the Holy Aedicule samples, which is however, a characteristic accessory phase for the Carrara locality. In addition, their fabric is not homeoblastic-polygonal, as described for the Carrara marbles [12,18].

The final variety to be examined is the Proconnesian marble. In the isotopic diagram (Figure 17), it is clear that all the studied samples plot in a very narrow field in the center of the Proconnesos- 1 subfield, indicating a critically similar isotopic signature between the Holy Aedicule samples and the published data on Proconnesos marbles $([15,16])$. The observed "mortar-type" heteroblastic fabric is another significant similarity that should not be neglected and points toward a Proconnesian provenance for the studied samples. This is also enhanced by the remarked accessory mineralogical components, (phlogopite \pm other micas, e.g., muscovite+apatite+minor dolomite+pyrite). Furthermore, in terms of MGS values, which range from 1.6-2.3 mm (mostly around $2 \mathrm{~mm}$ ), the observed values fit well in the field of the published data.

Taking into consideration all aforementioned data, and having excluded other marble-producing localities with similar isotopic signature, it is strongly suggested that the examined marbles of the Holy Aedicule originate from the Proconnesos island quarries. 


\subsection{Proconnesos Quarries: Intra-Site Discriminations}

The Proconnesian marble is one of the most popular white marbles used in antiquity [16], attracting the interest of the scientific community in relation to provenance studies in archaeometry. Its use flourished during the Roman era, with numerous buildings and art materials (sarcophagi, sculptures etc.) made out of Proconnesos marble. During the second and third centuries AD, the use of Proconnesian marble has been documented throughout the whole Imperial territory [16,71-73]. This continued to the Byzantine times, since the close proximity of the quarries to the capital city of Constantinople was an additional advantage.

More than twenty-three ancient and contemporary quarrying locations have been identified so far in the northern part of Proconnesos (Marmara Island) [16]. In many of them, remnants of sculpted and or half-worked items are present (e.g. columns). The abundance of quarries and the widespread use of their marbles lead to the publication of detailed works, defining mineralogical and isotopic signatures of these quarries, in an attempt to define any possible intra-site discriminating features $[15,16,18]$.

Based on isotopic characterization, Asgari and Mathews (1995) [15] already distinguished two possible Proconnesos marble varieties: The Proconnesos-1 and the Proconnesos-2, with the later exhibiting highly negative $\delta^{18} \mathrm{O}$ values. This discrimination was later confirmed by Gornoni et al. 2002 [18] and Attanasio et al. 2008 [16], who extended knowledge on the Proconnesian marble properties. Attanasio et al. 2008 [16] proposed the use of an isotopic threshold $\left(\delta^{18} \mathrm{O}=-5.00\right)$, as a discriminating factor of the two varieties. As shown in Figure 18, the Holy Aedicule samples are characterized by relatively low-negative $\delta^{18} \mathrm{O}$ values, ranging from -2.49 to -1.13 , thus revealing an isotopic affinity to the Proconnesos-1 variety.

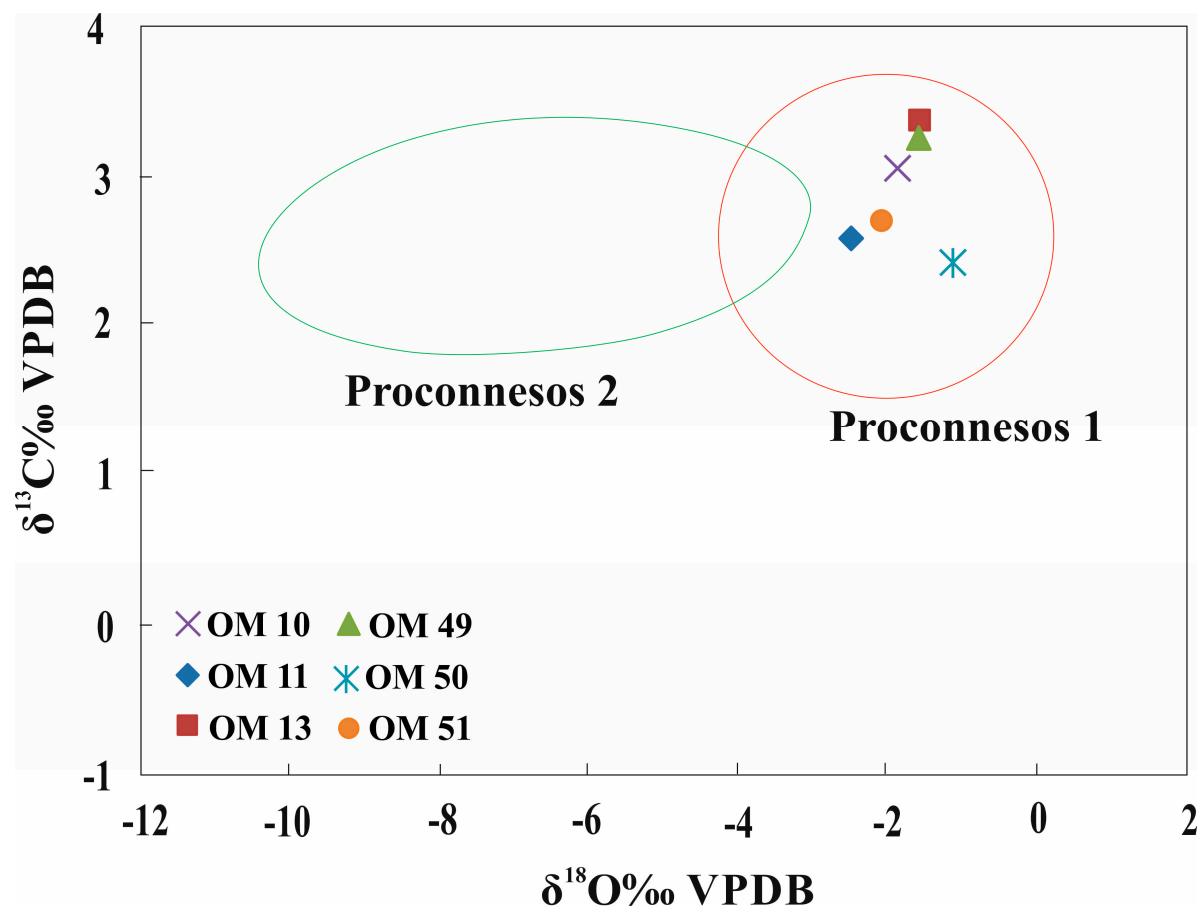

Figure 18. Isotopic discrimination plot between the so-called varieties Proconnesos- 1 and Proconnesos- 2 . Fields for Proconnesos-1 and Proconnesos-2 varieties are adopted from Attanasio et al., 2008 [16].

Even though the isotopic values for the majority of the quarries display significant overlaps, a fact that allows limited chances for safe intra-site topographical discriminations, an effort was made to couple selected values of Proconnesos quarries with the respective values displayed by the marble samples of the Holy Aedicule. 
In particular, for each sample of the Holy Aedicule, comparison was made with the published MGS values and isotopic values $\left(\delta^{18} \mathrm{O}\right.$ and $\left.\delta^{13} \mathrm{C}\right)$, as given by Attanasio et al. 2008 [16], for the quarries that the later examined, excluding the modern-only quarries and the open-air museum artifacts.

In Table 5, the comparison of isotopic and MGS values between the Holy Aedicule samples and the literature data for quarrying locations on Proconnesos island [16] is presented. Highlighted boxes indicate pairing of the isotopic values of the Holy Aedicule samples (both $\delta^{18} \mathrm{O}$ and $\delta^{13} \mathrm{C}$ ) with the published range of values for a certain quarry, while $(\sqrt{ })$ stands for pairing of the MGS values as well. Obviously, when both aforementioned criteria are satisfied, the probability of a sample deriving from that specific quarry is increased.

Table 5. Comparison of isotopic and MGS values between the Holy Aedicule samples and literature data for quarrying locations on Proconnesos island (Attanasio et al. 2008 [16]). Highlighted boxes indicate pairing of the isotopic values of a Holy Aedicule sample (both $\delta^{18} \mathrm{O}$ and $\delta^{13} \mathrm{C}$ ) to the published range of values for a certain quarry; $(\sqrt{ })$ stands for respective pairing regarding the MGS values.

\begin{tabular}{|c|c|c|c|c|c|c|}
\hline \multirow[t]{2}{*}{ Quarry } & \multicolumn{6}{|c|}{ Samples from the Holy Aedicule } \\
\hline & OM10 & OM 11 & OM13 & OM49 & OM50 & OM51 \\
\hline Altintaş & $\sqrt{ }$ & & & & $\sqrt{ }$ & $\sqrt{ }$ \\
\hline Harmantaş & & & & & $\sqrt{ }$ & \\
\hline Filiz & & & & & & \\
\hline OC13 & & $\sqrt{ }$ & & & & \\
\hline Mandira & & $\sqrt{ }$ & & & $\sqrt{ }$ & $\sqrt{ }$ \\
\hline Saraylar & & & & & & \\
\hline $\mathrm{C} 1$ & & $\sqrt{ }$ & & $\sqrt{ }$ & & \\
\hline C2 & $\sqrt{ }$ & $\sqrt{ }$ & & & & \\
\hline C3 & $\sqrt{ }$ & & & & & \\
\hline C4 & & $\sqrt{ }$ & & & & \\
\hline C5 & & & & & & \\
\hline $\mathrm{C} 5 \mathrm{~b}$ & $\sqrt{ }$ & & $\sqrt{ }$ & $\sqrt{ }$ & & \\
\hline C5t & & $\sqrt{ }$ & & & & \\
\hline C6 & & $\sqrt{ }$ & & & $\sqrt{ }$ & \\
\hline $\mathrm{C} 6 \mathrm{~b}$ & & & & & & \\
\hline C7 & & & & & & \\
\hline C7i & 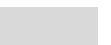 & $\sqrt{ }$ & & & & \\
\hline C8 & & & & & & \\
\hline C9 & & & & & & \\
\hline C10 & & & & & & \\
\hline C11 & & $\sqrt{ }$ & & & & \\
\hline C12 & $\sqrt{ }$ & & & & & \\
\hline $\mathrm{C} 12 \mathrm{~s}$ & & & & & & \\
\hline C13 & & $\sqrt{ }$ & & & & \\
\hline C14 & $\sqrt{ }$ & $\sqrt{ }$ & & & & \\
\hline C15 & & $\sqrt{ }$ & & & & \\
\hline C16 & & & & & & \\
\hline
\end{tabular}

Based on this comparison, seven quarries, namely the Filiz, Saraylar, C5, C6b, C7, C8 and C16, demonstrate values which exclude them as sources of raw material for the examined samples of the Holy Aedicule.

According to the set criteria, sample OM13, which corresponds to the internal facing opposite the Holy Tomb, could have derived only for the C5b quarry. Sample OM49, which corresponds to the marble fragment found inside the Holy Tomb, could have originated only from quarries C1 and C5b. Although intra-site discrimination can be considered successful for the aforementioned samples, this is not the case for samples OM10 and OM11, which correspond to the lower and the upper plate of the Holy Tomb respectively. OM 10 could have originated from quarries Altintas, C2, C3, C12, C14 and $\mathrm{C} 5 \mathrm{~b}$; the latter being the only common quarry with samples OM13 and OM49. OM11 is correlated 
with quarries OC13, Mandira, C1, C2, C4, C5t, C6, C7i, C11, C13, C14, C15, making any comparison with other samples difficult.

Samples OM50 and OM51 were taken from the internal facings of the Chapel of the Angel, right and left of the entrance to the Holy Tomb Chamber, respectively. OM50 could have been quarried from Altintas, Harmantas, Mandira and C6, while OM51 could have originated only from Altintas and Mandira quarries.

\subsection{Discussing the Petrographic and Isotopic Analysis Results in Relation to Historical Sources, Data and Testimonies}

Mineralogical, petrographical and isotopic investigations indicate that the Holy Aedicule marble samples were quarried at the island of Proconnesos. Intra-site discrimination demonstrated that the samples are of the Proconnesos- 1 variety, while further topographical investigation suggested possible quarries from which each sample could have originated from.

These results will herein be discussed in relation to existing historical data and a previous archaeometry study of mortar samples from the Holy Aedicule [69], in order to discuss the use of Proconnesian marble to enclose the Holy Tomb, as well as to decorate the interior of the Holy Aedicule structure.

It must be noted that, although historical testimonies of pilgrims visiting the Tomb of Christ throughout the centuries are of great significance, their interpretation is difficult and may sometimes be misleading or even contradictory. Usually, their intention is not to document the Holy Tomb and the structure surrounding it, but to describe this most holy site glorifying the resurrection of Christ (it is frequently addressed as "holy of holies"), while the variations in metric systems throughout the ages does not facilitate comparisons. Thus, their accounts are useful to the interpretation of archaeometric findings, however, cannot always be taken into account in a literal and conclusive manner. In Table 6, the most important historical sources and testimonies related to the presence of marble facings surrounding the Tomb of Christ in the Holy Aedicule structure, are presented in chronological order.

Table 6. References to the Tomb of Christ and the interior marble facings of the Holy Aedicule.

\begin{tabular}{ll}
\hline Era & Basic References to Marble Facings of the Tomb and the Holy Aedicule \\
\hline 326/327 AD: & Constantine, in a letter to Macarius, declares: "As to the columns or marble, you should \\
after a survey yourself write promptly to us about what you may consider to be of most value \\
and use, so that whatever quantity and kind of materials we may learn from your letter to be \\
needful may be competently supplied from all sources" in order for the "world's most \\
miraculous place" to "be worthily embellished" [49]. \\
Eusebius (Eusebius of Caesarea, counselor of Constantine the Great) states that: "First \\
of all, then, he (Constantine) adorned the sacred cave itself, as the chief part of the whole work, \\
and the hallowed monument at which the Angel radiant with light had once declared to all that \\
regeneration which was first manifested in the Savior's person" [50], the cave was "decked out \\
and decorated with superb columns and full ornamentation, brightening the solemn cave with \\
all kinds of artwork" [49]. \\
$\begin{array}{l}\text { Egeria offers a detailed account of her pilgrimage to the Holy Sites and describes: "And } \\
\text { what shall I say of the decoration of the fabric itself, which Constantine, at his mother's } \\
\text { instigation, decorated with gold, mosaic, and costly marbles, as far as the resources of his } \\
\text { kingdom allowed him, that is, the greater church, as well as the Anastasis, at the Cross, and the } \\
\text { other holy places in Jerusalem" [74]. } \\
\text { Abbot Daniel (Daniel of Kiev) describes: "it is a small cave hewn in the rock, having an } \\
\text { entrance so low that a man can scarcely get through by going on bended knees; its height is } \\
\text { inconsiderable, and its dimensions, equal in length and breadth, do not amount to more than } 4 \\
\text { cubits. When one has entered the grotto by the little entrance, one sees on the right hand a sort } \\
\text { of bench, cut in the rock of the cavern, upon which the body of our Lord Jesus Christ was laid; it } \\
\text { is now covered by marble slabs. This sacred rock, which all Christians kiss, can be seen through } \\
\text { three small round openings on one side" [75]. }\end{array}$ \\
\hline $1105-1107$ AD:
\end{tabular}


Table 6. Cont.

\begin{tabular}{|c|c|}
\hline Era & Basic References to Marble Facings of the Tomb and the Holy Aedicule \\
\hline 1322 AD: & $\begin{array}{l}\text { John Maundeville in his pilgrimage recount in 1322, states that "it is not long since the } \\
\text { Sepulchre was all open, that men might kiss it and touch it" [76]. }\end{array}$ \\
\hline 1345 AD: & $\begin{array}{l}\text { An anonymous English traveler describes the marble plate covering the Tomb of Christ: } \\
\text { The Tomb is "decorated with a porphyry slab, that had lips on the sides, and in the middle of } \\
\text { the slab there was cut a streak" [51]. This description is close to the upper marble plate in } \\
\text { place today. However, it must be noted that either the use of the word "porphyry" } \\
\text { inaccurately describes the distinctive amber hue of this marble plate or the marble plate } \\
\text { in place today is a later addition presenting rounded edges and a streak in the middle } \\
\text { as well. }\end{array}$ \\
\hline 1347 AD: & $\begin{array}{l}\text { Niccolò da Poggibonsi describes three port-holes in a vertical slab encasing the Tomb, } \\
\text { from which the rock burial surface is visible [51]. This is the last pilgrim account of the } \\
\text { three port-holes in the vertical slab. }\end{array}$ \\
\hline 1570 AD: & $\begin{array}{l}\text { Fra Bonifacio da Ragusa, describing his reconstruction: "It seemed necessary to level the } \\
\text { structure to the ground, so that that which would be constructed might be stronger and last } \\
\text { longer. When the existing one was destroyed, the tomb of the Lord appeared clearly to our eyes, } \\
\text { carved in the rock. In it could be seen depicted two angels, of whom one had an inscription which } \\
\text { said: 'He is risen and is not here', whereas the other, indicating the tomb, proclaimed: 'Behold } \\
\text { the place where he has been laid'. As soon as the figures of these two angels came into contact } \\
\text { with the air, they almost completely disappeared. When it was necessary to remove one of the } \\
\text { slabs of alabaster that covered the tomb on which the holy mystery of the Mass is celebrated, there } \\
\text { appeared to us that ineffable place in which for three days the Son of Man reposed...." [51,77]. }\end{array}$ \\
\hline 1724-1744 AD: & $\begin{array}{l}\text { Elzear Horn claims that Bonifacio covered the exterior of the Holy Aedicule with } \\
\text { marble slabs and columns in order to beautify it. Also, when describing his own } \\
\text { designs of the Holy Aedicule he says that: "No. } 20 \text { " [this is in reference to the exterior } \\
\text { facades of the Aedicule] "indicates old marble slabs of white colour, which are here and there } \\
\text { striped with grey; with these (slabs) the zealous piety of the Most Rev. Fr. Boniface, Superior of } \\
\text { the Holy Land, caused also the interior parts of the Tomb to be covered in the year } 1555 \text { AD" } \\
\text { [78]. This description of white marbles with grey stripes could refer to marbles of } \\
\text { Proconnesos. "The said slabs [referring to the exterior white marble facings with grey } \\
\text { stripes] had first been attached elsewhere, and then were placed here, as also the } 10 \text { small } \\
\text { columns ... " [78]. This is a direct and absolute reference to re-use of marble members. } \\
\text { Describing the Chapel of the Angel, the western part of it "is in the form of a half circle" } \\
\text { and "the upper part of which is adorned with multicoloured tapestries. The lower is covered } \\
\text { with marble slabs", while the eastern part of the Chapel of Angel is "square in form". } \\
\text { While describing the Tomb Chamber "... .between the marble slabs which cover the walls, } \\
\text { there is a distance of } 6 \text { feet and } 2 \text { palms..." [78]. Thus, both the Tomb Chamber and the } \\
\text { Chapel of Angel where adorned with marble facings at the time of Horn's recount. }\end{array}$ \\
\hline 1809 AD: & $\begin{array}{l}\text { Maximos Simaios in his description of the works conducted during the reconstruction } \\
\text { by Kalfa Komnenos at the Holy Tomb area states that: "Komnenos opened the west end } \\
\text { and encountered an indescribably sweet Odour rising up [ ... ] There was a blocking on the } \\
\text { south side consisting of two 'marbles'. Above 'this' there were two more 'marbles', one above } \\
\text { another, each one the same" (quoted from Biddle } 1999 \text { [51]). } \\
\text { He also states that: "the Aedicule, in need of total repair, was demolished... All the marbles } \\
\text { present in the cave of the Tomb were collected and stored... Thus, the holy burial cave was } \\
\text { revealed... " and "At its north and south part, the burial chamber is hewn in the natural rock } \\
\text { while the eastern and western part, as well as the roof, are built" }\end{array}$ \\
\hline
\end{tabular}

Historical sources and the surviving accounts of pilgrims visiting the Holy Aedicule, already from the fourth century, describe a glorious monument surrounding the Tomb of Christ adorned with marbles and other decorative features. Constantine declares his intention of bringing materials from "all sources". From Eusebius's account it seems that the Tomb of Christ "the sacred cave" was the chief part of the whole work during the construction of the Constantinean complex and was lavishly adorned and "brightened up". Historical sources reveal that Constantine and Helena brought large quantities of marble to Jerusalem [54]. Thus, according to the historical data, it is likely that the Holy 
Aedicule structure was adorned with marble facades from the Constantinean era, and the Tomb of Christ was cladded with marble in order to protect it.

Optical Stimulated Luminescence (OSL) dating conducted in a previous study [69] supports this theory. Indeed, the bedding mortar connecting the fragmented lower marble plate (corresponding to sample OM10) with the original burial rock surface, was found to be of an age of $1670 \pm 230$ years, thus the calendar centered age of $345 \mathrm{AD}$, corresponding to the era of the Constantinean constructions. The fact that a number of pilgrims speak of the Tomb as "cut out of the rock" is perhaps connected to the three port-holes of the vertical marble slab, which allowed visibility to the original burial rock surface itself (e.g., Abbot Daniel, in the early 11th century states "This sacred rock, which all Christians kiss, can be seen through three small round openings on one side ... ").

The cladding of the Holy Tomb with marble from as early as the Constantinean era, was obviously installed as, without protection, the pilgrims would have all cut out a piece of the rock surface of the Holy Tomb material as a keepsake. The use of white marble from Proconnesos is an excellent selection for the Tomb of Christ, as its color and texture reflect light, symbolizing regeneration, with the proper amount of required simplicity. Furthermore, as already mentioned in the Introduction section, Proconnesos marble was extremely popular and widely used in imperial buildings during the Constantinean era. Thus, the lower plate, originating from Proconnesos, was installed at the time of Constantine; it was preserved throughout the centuries, even after being fragmented, and is still present, although not visible, within the Tomb of Christ under the upper plate worshiped today.

The marble fragment (sample OM49), found within the Tomb of Christ when it was opened by the NTUA interdisciplinary team, was also determined as Proconnesian marble in this study. This fragment is of the same thickness as the lower Constantinean marble plate $(\sim 3.3 \mathrm{~cm})$. The location where it was found (inside the Tomb, indicating its importance) and its identical dimension of thickness with the lower marble plate (OM10), suggests that it is perhaps a fragment of the decorative edge from the missing part of the lower plate. If this is the case, the original marble member was extracted from the quarry C5b (Table 5).

The upper plate (sample OM11), still worshiped today, is also Proconnesian marble and, as already mentioned, its surface discoloration, giving the stone an amber-hue, is related to the daily application of myrrh on the surface, as a religious ritual, continuing for centuries up to today. The upper plate, due to its position, was definitely placed at a later date than the lower Constantinean plate, however it is very difficult to pinpoint the exact date it was placed; it was probably in place by $1345 \mathrm{AD}$, as it is at that time mentioned by an anonymous English pilgrim. The presence of more than one slabs is mentioned by Bonifacio da Ragusa, as stated in Table 6, however it cannot be certain which slabs he is referring to and whether he installed the upper plate worshiped today or if it preexisted. Sample OM11 could have been quarried from a number of quarrying locations of the Proconnesos island (Table 5), thus any comparison with other samples could not lead to safe conclusions.

In any case, a marvelous continuity of material both in relation to its memory and its use, is highlighted by the fact that the two marble plates covering the Tomb of Christ, although placed centuries apart, are both marbles that originate from the island of Proconnesos.

The marble sample taken from the marble facings of the interior of the Tomb Chamber, opposite the Tomb of Christ, and in particular from a slab of the south interior wall (sample OM13), is also proven to be Proconnesian marble in the current study. In a previous study, OSL dating was conducted on a mortar behind this particular slab and found to correspond to an age of $450 \pm 68$ years, thus to the central calendar age of 1570, corresponding to the Bonifacio da Ragusa restoration [69]. In parallel, a mortar selected from behind a marble slab above the one examined in this study (OM13), was dated to $335 \mathrm{AD}$ (calendar centered age) \pm 235 years, that is the Constantinean Aedicule.

Thus, it is highly likely that the interior of the Tomb Chamber was adorned with Proconnesian marbles from the time of Constantine. Therefore, Bonifacio da Ragusa, either substituted certain marble slabs of the Tomb Chamber facings, using Proconnesos marble in order to be consistent with the material already adorning the Tomb Chamber, or reinstalled certain marble slabs already present, 
which had shifted out of position or unfastened. The later is more possible, especially taking into account Horne's reference related to the Bonifacio interventions "The said slabs had first been attached elsewhere, and then were placed here, as also the 10 small columns ... ". Horne, of course, is referring to the exterior facings, however, his statement is indicative of marble members re-use as a common practice throughout the ages, which could have been applied to the interior facings as well. This complicates the interpretation and interconnection of the historical and analytical evidence related to the architectural and structural evolution of the Holy Aedicule.

OM13 is the only sample which could have originated only from one of the examined quarries and in particular from C5b. Thus, if this marble member was first installed in the Constantinean era and Bonfacio da Ragusa reinstalled it, and taking into account that the lower tomb plate (OM10) was also installed in the Constantinean era, perhaps both members were quarried from $C 5 b$, which is the only common quarry of origin for both samples. Furthermore, quarry $\mathrm{C} 5 \mathrm{~b}$ is also a common origin quarry with sample OM49, which is the marble fragment, perhaps the decorative edge of the lower marble plate, as already mentioned. However, it is certain that the marble facing slab examined (OM13) does not match with any of the possible origin quarries either of the upper tomb plate (OM11) or of the facings of the Chapel of the Angel (OM50, OM51).

The two marble samples (OM50, OM51) from the west interior wall of the Chamber of the Angel are also Proconnesian marble. The Chamber corresponding to the Chapel of the Angel, as already mentioned, is a later addition, thus the marble facings were probably installed at least after 1099 AD in the era of the Crusaders. However, it should be noticed, that their presence from much earlier, as part of the exterior marble facings of the ciborium-type earlier structure, cannot be entirely excluded. In addition, they could also have been installed at later era, either during the Bonifacio renovation or during the major reconstruction of Kalfa Komnenos in 1810. OM 50, in accordance to Table 5, could have originated from the quarries Altintaş, Harmantaş, Mandira and C6, while OM51, could have originated from Altintaş and Mandira. They therefore present two common origin quarries, that is, Altintass and Mandira. In any case, they do not present any common quarries with OM13 and with OM49, thus strengthening interpretation that they are a later addition.

It is extremely interesting and of great archaeological importance, that throughout the centuries, Proconnesian marble was the material of choice for the interior of the Holy Aedicule, both in the Tomb Chamber and the Chapel of the Angel. The continuity of the memory of the material and its grasping symbolism survived over 15 centuries, from its first use from Constantine's architects to the time of Komnenos, whom brought a large quantity of Proconnesos marbles to Jerusalem in order to use for architectural elements throughout the Church of Resurrection [57].

Thus, one more monument is added to the long and magnificent list of important monuments adorned with Proconnesian marble. In parallel, if the need arises for replacement of slabs in the interior of the Holy Aedicule, Proconnesian marble can be selected as the most compatible material and one that carries the light from the beginning of the Holy Aedicule.

\section{Conclusions}

Petrographic and isotopic analysis was implemented to study the white marbles of the Holy Aedicule and the Tomb of Christ. The examined marble samples display a characteristic heteroblastic fabric, which is characterized as "mortar-type". They comprise mostly of calcite with minor presence of dolomite, micas (phlogopite, muscovite), apatite and pyrite. Their MGS values range from 1.6 to $2.3 \mathrm{~mm}$, gathered mostly around $2 \mathrm{~mm}$. Their isotopic signature is characterized by $\delta^{18} \mathrm{O}$ values ranging from -2.49 to -1.13 (\%o V-PDB) and by $\delta^{13} \mathrm{C}$ values ranging from 2.43 to 3.37 (\%o V-PDB). The techniques employed proved to be adequate for the identification of their provenance and the aforementioned data suggest that the Holy Aedicule white marbles examined herein, originate from the island of Proconnesos and in particular they belong to the variety type Proconnesos-1.

Furthermore, an intra-site discrimination was attempted by comparing published MGS values and isotopic analysis data of Proconnesos quarries, with the respective data of the Holy Aedicule 
samples as measured herein. These results in correlation with historical data, allows for further interpretations. The fragmented lower marble plate (corresponding to sample OM10), is in fact the initial cladding of the original burial rock surface attributed to the Constantinean era. The marble fragment (sample OM49), found within the Tomb of Christ, which presented the same thickness as the lower Constantinean marble plate, is perhaps a fragment of the decorative edge from the missing part of the lower plate; if this is the case, the original marble member was extracted from the quarry C5b, which is the only common quarry between these two samples. The upper plate of the Tomb (sample OM11), was added several centuries later, however, no definite conclusion regarding the era that it was placed can be drawn; furthermore, intra-site discrimination could not provide any safe conclusions regarding the exact Proconnesos quarry it originated from.

The marble sample taken from the marble facings of the interior of the Tomb Chamber, opposite the Tomb of Christ (sample OM13) was most probably placed into its current position at the time of the Bonifacio da Ragusa restoration, without excluding the possibility that this member was present from the Constantinean era, since marble members re-use was a common practice throughout the centuries. The particular sample could have originated only from the ancient quarry C5b. The two marble samples (OM50, OM51) from the west interior wall of the Chamber of the Angel, were collected from marble members, which were placed probably during the Crusaders construction phase, without, however, excluding the Bonifacio renovation or even the major reconstruction of Kalfa Komnenos in 1810. Altintaş and Mandira are the only common origin quarries for these two samples and it is definite that they could not have originated from the same quarry as OM13 and OM49 (C5b).

Hopefully, the discussion made in the current research, interconnecting the results with aspects and events of the Holy Aedicule's construction history, will assist in revealing its evolution. It is extremely interesting and of great archaeological importance, that throughout the centuries, from the Constantinean era up to the Komnenos restoration, Proconnesian marble, and in particular the Proconnesos-1 variety, was the material of choice both for the cladding of the Holy Tomb, as well as for the interior facings of the Holy Aedicule.

Author Contributions: A.M. scientifically supervised and coordinated all aspects of the presented research; E.T.D. and M.A. conducted the in-situ investigation and sampling, conducted the correlation of the research results with the historical sources and data; A.K. assisted in the preparation of the original draft regarding the historical data; C.P. and G.E. conducted and evaluated the mineralogical and petrographical investigations; C.M. evaluated the isotopic analyses and correlated mineralogical, petrographical and isotopic data; E.T.D., M.A. and C.M. conducted the original draft preparation, as well as the writing-review and editing of the manuscript.

Funding: This research received no external funding. It is a pro bono post-program research, following the rehabilitation of the Holy Aedicule, aiming to shed light on the construction history and highlight the values of the Holy Aedicule.

Acknowledgments: The study and the rehabilitation project of the Holy Aedicule became possible and were executed under the governance of His Beatitude Patriarch of Jerusalem, Theophilos III. The Common Agreement of the Status Quo Christian Communities provided the statutory framework for the execution of the project; His Paternity the Custos of the Holy Land, Archbishop Pierbattista Pizzaballa (until May 2016-now the Apostolic Administrator of the Latin Patriarchate of Jerusalem), Fr. Francesco Patton (from June 2016), and His Beatitude the Armenian Patriarch of Jerusalem, Nourhan Manougian, authorized His Beatitude the Patriarch of Jerusalem, Theophilos III, and NTUA to perform the project. Contributions from all over the world secured the project's funding. Worth noting Mica Ertegun's and Jack Shear's donations through WMF, Aegean Airlines et al. The interdisciplinary NTUA team for the Protection of Monuments, Em. Korres, A. Georgopoulos, A. Moropoulou, C. Spyrakos, Ch. Mouzakis, were responsible for the rehabilitation project and A. Moropoulou, as Chief Scientific Supervisor, was responsible for its scientific supervision.

Conflicts of Interest: The authors declare no conflict of interest. The funders had no role in the design of the study; in the collection, analyses, or interpretation of data; in the writing of the manuscript, or in the decision to publish the results. 


\section{References}

1. Mrozek-Wysocka, M. Ancient marbles: Provenance determination by archaeometric study. In Geoscience in Archaeometry. Methods and Case Studies; Michalska, D., Szczepaniak, M., Eds.; Wydawnictwo Naukowe Bogucki: Poznań, Poland, 2014; pp. 99-122.

2. Gorgoni, C.; Lazzarini, L.; Pallante, P.; Turi, B. An updated and detailed mineropetrographic and C-O stable isotopicreference database for the main Mediterranean marbles used in antiquity. In Proceedings of the 5th ASMOSIA Conference, Boston, MA, USA, 12-15 June 1998; pp. 1-25.

3. Lazzarini, L. Archaeometric aspects of white and coloured marbles used in antiquity: The state of the art. Periodico di Mineralogia. Per. Miner. 2004, 73, 113-125.

4. Lepsius, R. Griechische Marmorstudien; Philosophisch-historische Klasse; Abhandlungen der Königlichen Akadamie der Wissenschaften zu Berlin: Berlin, Germany, 1890; pp. 1-135.

5. Attanasio, D.; Brilli, M.; Ogle, N. The isotopic Signature of Classical Marbles; Studia Archaeologica; L'Erma di Bretschneider: Roma, Italy, 2006; p. 145.

6. Attanasio, D.; Bruno, M.; Yavuz, A.B. Quarries in the region of Aphrodias: The black and white marbles of Göktepe (Mugla, Turkey). J. Roman Archaeol. 2009, 22, 312-348. [CrossRef]

7. Herz, N.; Prichett, W.K. Marble in Attic Epigraphy. Am. J. Archaeol. 1953, 57, 71-83. [CrossRef]

8. Herz, N. Petrofabrics and classical archaeology. Am. J. Sci. 1955, 253, 299-305. [CrossRef]

9. Renfrew, C.; Springer, P.J. Aegean marble: A petrological study. Annu. Br. Sch. Athens 1968, 63, 45-66. [CrossRef]

10. Young, W.J.; Ashmole, B. The Boston relief and the Ludovisi Throne. Boston Bull. Mus. 1968, 66, 124-166.

11. Capedri, S.; Venturelli, G. Accessory minerals as tracers in the provenancing of archaeological marbles used in combination with isotopic and petrographic data. Archaeometry 2004, 46, 517-536. [CrossRef]

12. Antonelli, F.; Lazzarini, L. An updated petrographic and isotopic reference database for white marbles used in Antiquity. Rend. Lincei 2015, 26, 399-413. [CrossRef]

13. Craig, H.; Craig, V. Greek marble determination of provenance by isotopic analysis. Science 1972, 176, 401-403. [CrossRef]

14. Babcock, L.N. Accessory Minerals, $\delta^{13} \mathrm{C}$ and $\delta^{18} \mathrm{O}$, and Petrographic Structures of Pentelic and Proconnesian Quarry Marbles: Analysis with Nonmetric Multidimensional Scaling for Artifact Provenance. Ph.D. Thesis, The University of Georgia, Athens, GA, USA, 2012; 158p.

15. Asgari, N.; Matthews, K.J. The stable isotope analysis of marble from Proconnesos. In The Study of Marble and Other Stones Used in the Antiquity; Maniatis, Y., Herz, N., Basiakos, Y., Eds.; Archetype Publication: London, UK, 1995; pp. 123-129.

16. Attanasio, D.; Brili, M.; Bruno, M. The properties and identification of marble from Proconnesos (Marmara Island, Turkey): A new database including isotopic, EPR and petrographic data. Archaeometry 2008, 50, 747-774. [CrossRef]

17. Bruno, M.; Conti, L.; Lazzarini, L.; Pensabene, P.; Turi, B. The marble quarries of Thasos: An archeometric study. In Interdisciplinary Studies in Ancient Stone; ASMOSIA VI; Lazzarini, L., Ed.; Padova: Bottega dErasmo, Italy, 2002; pp. 157-162.

18. Gorgoni, C.; Lazzarini, L.; Pallante, P.; Turi, B. An updated and detailed mineropetrographic and C-O stable isotopic reference database for the main Mediterranean marbles used in antiquity. In Interdisciplinary Studies on Ancient Stone; Herrmann, J.J., Jr., Herz, N., Newman, R., Eds.; Archetype: London, UK, 2002; pp. $115-131$.

19. Bruno, M.; Lazzarini, L.; Soligo, M.; Turi, B.; Varti-Matarangas, M. A recently discovered ancient quarry at Karavos (Paros, Greece) and the characterization of its marble. In Parian Quarries, Marble and Workshops of Sculpture; Schilardi, D.U., Ed.; The Paros and Cyclades Institute of Archaeology: Athens, Greece, 2000.

20. Lazzarini, L.; Ponti, G.; Preite Martinez, M.; Rockwell, P.; Turi, B. Historical, technical, petrographic, and isotopic features of Aphrodisian marbles. In Interdisciplinary Studies in Ancient Stone; ASMOSIA 5; Herrmann, J.J., Herz, N., Newton, R., Eds.; Bottega dErasmo: Padova, Italy, 2002.

21. Matthews, K.J.; Moens, L.; Walker, S.; Waelkens, M.; De Paepe, P. The re-evaluation of stable isotopedata for Pentelic marble. In Ancient Stones: Quarrying, Trade and Provenance; Waelkens, M., Herz, N., Moens, L., Eds.; University Press: Leuven, Belgium, 1992; pp. 203-212. 
22. Pike, S. Preliminary results of asystematic characterization study of Mount Pentelikon, Attica, Greece. In Archéomatériaux: Marbles et Autres Roches; Schvoerer, M., Ed.; Presses Universitaires de Bordeaux: Pessac, France, 1999; pp. 165-170.

23. Goette, H.R.; Polikreti, K.; Vakoulis, T.; Maniatis, Y. Investigation of theblue-gray marble of Pentelikon andthe equivalent Hymettian: Possibleuses in antiquity. In Archéomatériaux: Marbles Etautres Roches; Schvoerer, M., Ed.; Presses Universitaires de Bordeaux: Pessac, France, 1999; pp. 83-90.

24. Maravelaki-Kalaitzaki, P. Black crusts and patinas on Pentelic marble from the Parthenon and Erechtheum (Acropolis, Athens): Characterization and origin. Anal. Chim. Acta 2005, 532, 187-198. [CrossRef]

25. Korres, E. From Pentelicon to the Parthenon; Melissa Publications: Athens, Greece, 2001.

26. Delegou, E.T.; Ntoutsi, I.; Kiranoudis, C.T.; Sayas, J.; Moropoulou, A. Advanced and Novel Methodology for Scientific Support on Decision-Making for Stone Cleaning. In Advanced Materials for the Conservation of Stone; Hosseini, M., Karapanagiotis, I., Eds.; Springer: Cham, Switzerland, 2018.

27. Palagia, O. Parian Marble and the Athenians. In Paria Lithos: Parian Quarries, Marble and Workshops of Sculpture, Proceedings of the First International Conference on the Archaeology of Paros and the Cyclades, Paros 2-5 October 1997, 1st ed.; Andromeda Books: Athens, Greece, 2000; pp. 347-354.

28. Bradley, M. The importance of colour on ancient marble sculpture. Art hist. 2009, 32, 427-457. [CrossRef]

29. Bashar, M.; Abbas, N. New marble sarcophagus from Syrian coast. Sci. Cult. 2015, 1, 17-26.

30. Tykot, R.H.; Herrmann, J.J.; van der Merwe, N.J.; Newman, R.; Allegretto, K.O. Thasian marble sculptures in European and American collections: Isotopic and other analyses. Asmosia 2002, 5, 188-195.

31. Larson, J. The conservation of marble monuments in churches. Conservator 1978, 2, 20-25. [CrossRef]

32. Bonazza, A.; Sabbioni, C.; Messina, P.; Guaraldi, C.; De Nuntiis, P. Climate change impact: Mapping thermal stress on Carrara marble in Europe. Sci. Total Environ. 2009, 407, 4506-4512. [CrossRef]

33. Herz, N.; Waelkens, M. (Eds.) Classical marble: Geochemistry, Technology, Trade; Kluwer Academic Publishers: Dordrecht, The Netherlands, 1988; Volume 153.

34. Monna, D.; Pensabene, P. Marmi dell' Asia Minore; Consiglio Nazionale delle Ricerche, Scienze Sussidiarie dell' Archeologia: Roma, Italy, 1977.

35. Marano, Y.A. The circulation of marble in the Adriatic Sea at the time of Justinian. In Ravenna: Its Role in Early Medieval Change and Exchange; Institute of Historical Research: London, UK, 2016; pp. 111-132.

36. Asgari, N. Roman and early Byzantine marble quarries of Proconnesos. In Proceedings of the X International Congress of Classical Archaeology, Ankara-tIzmir, Turkey, 23-30 April 1973; Akurgal, E., Ed.; Türk Tarih Kurumu Basimevi: Ankara, Turkey, 1978; Volumes 1-3.

37. Walker, S. The Marble Quarries of Proconnesos: Isotopic Evidence for the Age of the Quarries and for Lenos-Sarcophagi carved at Rome. In Marmi Antichi: Problemi d'impiego, di Restauro e d'identificazione; Pensabene, P., Ed.; L'Erma di Bretschneider: Rome, Italy, 1985; pp. 57-65.

38. Walker, S.; Matthews, K.J. The marbles of the Mausoleum. In Sculptors and Sculpture of Caria and me Dodecsnese; Jenkins, I., Waywell, G.B., Eds.; British Museum Press: London, UK, 1997; pp. 49-59.

39. Cramer, T. Die Marmore des Telephosfrieses am Pergamonaltar. Berliner Beirrage zur Archiiomeuie 1998, 15, 95-198.

40. Ward-Perkins, J.B. Roman Imperial Architecture; The Yale University Press: New Haven, CT, USA, $1981 ;$ p. 139.

41. Naddaf, M.; Al-Bashaireh, K.; Al Wacked, F. Characterization and provenance of marble chancel screens, Northern Jordan. Mediter. Archaeol. Archaeom. 2010, 10, 75-83.

42. Maniatis, Y.; Tambakopoulos, D.; Dotsika, E.; Wescoat, B.D.; Matsas, D. The sanctuary of the Great Gods on Samothrace, Greece: An extended marble provenance study. In Interdisciplinary Studies on Ancient stone, Proceedins of the IX ASMOSIA Conference (Tarragona, 2009); Istituto Català d'Arqueologia Clàssica: Tarragona, Spain, 2012; pp. 263-278.

43. Alexakis, E.; Delegou, E.T.; Lampropoulos, K.C.; Apostolopoulou, M.; Ntoutsi, I.; Moropoulou, A. NDT as a monitoring tool of the works progress and the assessment of materials and rehabilitation interventions at the Holy Aedicule of the Holy Sepulchre. Constr. Build. Mater. 2018, 189, 512-526. [CrossRef] 
44. Moropoulou, A.; Korres, E.; Georgopoulos, A.; Spyrakos, C.; Mouzakis, C.; Lambrou, E.; Pantazis, G.; Kavvadas, M.; Marinos, P.; Moropoulos, N.; Zafeiris, V.; Lampropoulos, K.; et al. Faithful Rehabilitation. History, culture, religion, and engineering all intertwined in a re-cent project in Jerusalem to rehabilitate and strengthen the site believed to be the tomb of Jesus of Nazareth. Modern methods, including 3-D laser scanning, Non Destructive Techniques and ground-penetrating radar, combined with careful documentation and design, revealed the secrets of how to help preserve and sustain the ancient site for future generations. J. Am. Soc. Civ. Eng. 2017, 78, 54-61.

45. Moropoulou, A.; Georgopoulos, A.; Korres, M.; Bakolas, A.; Labropoulos, K.; Agrafiotis, P.; Delegou, E.T.; Moundoulas, P.; Apostolopoulou, M.; Lambrou, E.; et al. Five-Dimensional (5D) Modelling of the Holy Aedicule of the Church of the Holy Sepulchre Through an Innovative and Interdisciplinary Approach. In Mixed Reality and Gamification for Cultural Heritage; Ioannides, M., Magnenat-Thalmann, N., Papagiannakis, G., Eds.; Springer: Cham, Switzerland, 2017.

46. Lavvas, G. The Holy Church of the Resurrection in Jerusalem; The Academy of Athens: Athens, Greece, 2009.

47. Balodimos, D.; Lavvas, G.; Georgopoulos, A. Wholly Documenting Holy Monuments. CIPA XIX. Int. Arch. Photogramm. Remote Sens. 2003, 34, 5.

48. Lampropoulos, K.C.; Korres, M.; Moropoulou, A. A transdisciplinary approach to reveal the structural evolution of the Holy Aedicule in the Church of the Holy Sepulchre. In Nondestructive Evaluation and Monitoring Technologies, Documentation, Diagnosis and Preservation of Cultural Heritage; Osman, A., Moropoulou, A., Eds.; Springer Nature: Basingstoke, UK, in press.

49. Cameron, A.; Hall, S. (Eds.) Eusebius' Life of Constantine; Clarendon Press: Oxford, UK, 1999.

50. Pamphilus, S. Eusebius Book III; Chapter XXXI The Sacred Writings of Eusebius Pamphilus (Annotated Edition); Jazzybee Verlag: Altenmunster, Germany, 2012.

51. Biddle, M. The Tomb of Christ; Sutton: Gloucestershire, UK, 1999.

52. Marek, M. How to reverse the decline of an empire? Two Byzantine case studies: Herakleios and Alexios Komnenos. Graeco-Lat. Brun. 2016, 21, 119-134.

53. Howard-Johnston, J. Heraclius' Persian Campaigns and the Revival of the East Roman Empire, 622-630. War Hist. 1999, 6, 1-44. [CrossRef]

54. Michael, G.; Past, M. Monumental Present: Building with Antiquities in the Mediaeval; Brill: Boston, MA, USA, 2009.

55. Varvounis, M.G. The Holy Tomb and the Church of Resurrection; Chelandion Publications: Athens, Greece, 2009; pp. 37-46. (In Greek)

56. Lavvas, G. The All-Holy Church of Resurrection in Jerusalem. Corpus 2004, 60, 30-47.

57. Mitropoulos, T. The Church of Holy Sepulchre-The Work of Kalfas Komnenos; European Centre of Byzantine and Post-Byzantine Monuments: Thessaloniki, Greece, 2009.

58. Patrich, J. The Edicule in the Church of the Holy Sepulchre-Biddle Martin, the Tomb of Christ (Sutton Publishing Ltd., Stroud, Glos. 1999). J. Roman Archaeol. 2002, 15, 688-690. Available online: https://www.cambridge.org/core/journals/journal-of-roman-archaeology/article/edicule-in-the-churchof-the-holy-sepulchre-martin-biddle-the-tomb-of-christ-sutton-publishing-ltd-stroud-glos-1999-pp-xii172-103-figs-including-colour-isbn-0750919264-25/7E5FC29153F52B752E6E63B2B313C8BC (accessed on 25 April 2019). [CrossRef]

59. Pringle, D. The Churches of the Crusader Kingdom of Jerusalem: A Corpus; Cambridge University Press: New York, NY, USA, 2007; Volume 3.

60. Freeman, Fox, and Partners, Church of the Holy Sepulchre, Jerusalem. Report. 1947.

61. Moropoulou, A.; Korres, E.; Georgopoulos, A.; Spyrakos, C. Materials and Conservation, Reinforcement and Rehabilitation Interventions in the Holy Edicule of the Holy Sepulchre; NTUA: Athens, Greece, 2016; ISBN 978-618-82612-0-4.

62. Moropoulou, A.; Korres, E.; Georgopoulos, A.; Spyrakos, C.; Mouzakis, C.; Lampropoulos, K.C.; Apostolopoulou, M.; Delegou, E.T.; Alexakis, E. The rehabilitation of the Holy Aedicule. In Proceedings of the XXXIII Convegno Internazionale Scienza e Beni Culturali; Trasferimenti, Contaminazioni, Ibridazioni; Le Nuove Frontiere del Restauro: Bressanone, Italy, 2017; pp. 27-30.

63. Moropoulou, A.; Korres, E.; Georgopoulos, A.; Spyrakos, C.; Mouzakis, C. Presentation upon completion of the Holy Sepulchre's Holy Aedicule Rehabilitation; NTUA: Athens, Greece, 2017; p. 12. ISBN 978-618-82196-4-9. 
64. Moropoulou, A.; Korres, M.; Georgopoulos, A.; Spyrakos, C.; Mouzakis, C.; Lampropoulos, K.C. and Apostolopoulou, M. The Project of the Rehabilitation of Holy Sepulchre's Holy Aedicule as a Pilot Multispectral, Multidimensional, Novel Approach Through Transdisciplinarity and Cooperation in the Protection of Monuments. In International Conference on Transdisciplinary Multispectral Modeling and Cooperation for the Preservation of Cultural Heritage; Springer: Berlin/Heidelberg, Germany, 2018; pp. 3-25.

65. Apostolopoulou, M.; Delegou, E.T.; Alexakis, E.; Kalofonou, M.; Lampropoulos, K.C.; Aggelakopoulou, E.; Bakolas, A.; Moropoulou, A. Study of the historical mortars of the Holy Aedicule as a basis for the design, application and assessment of repair mortars: A multispectral approach applied on the Holy Aedicule. Constr. Build. Mater. 2018, 181, 618-637. [CrossRef]

66. Spyrakos, C.C.; Maniatakis, C.A.; Moropoulou, A. Preliminary Assessment of the Structural Response of the Holy Tomb of Christ Under Static and Seismic Loading. In International Conference on Transdisciplinary Multispectral Modeling and Cooperation for the Preservation of Cultural Heritage; Springer: Berlin/Heidelberg, Germany, 2018; pp. 44-57.

67. Alexakis, E.; Kapassa, E.; Touloupou, M.; Kyriazis, D.; Georgopoulos, A.; Moropoulou, A. Innovative Methodology for Personalized 3D Representation and Big Data Management in Cultural Heritage. In International Conference on Transdisciplinary Multispectral Modeling and Cooperation for the Preservation of Cultural Heritage; Springer: Berlin/Heidelberg, Germany, 2018.

68. Moropoulou, A.; Farmakidi, C.M.; Lampropoulos, K.; Apostolopoulou, M. Interdisciplinary planning and scientific support to rehabilitate and preserve the values of the Holy Aedicule of the Holy Sepulchre in interrelation with social accessibility. Sociol. Anthropo. 2018, 6, 534-546. [CrossRef]

69. Moropoulou, A.; Zacharias, N.; Delegou, E.T.; Apostolopoulou, M.; Palamara, E.; Kolaiti, A. OSL mortar dating to elucidate the construction history of the tomb chamber of the Holy Aedicule of the Holy Sepulchre in Jerusalem. J. Archaeol. Sci.: Rep. 2018, 19, 80-91. [CrossRef]

70. Lampropoulos, K.C.; Moropoulou, A.; Korres, M. Ground penetrating radar prospection of the construction phases of the holy Aedicula of the holy sepulchre in correlation with architectural analysis. Constr. Build. Mater. 2017, 155, 307-322. [CrossRef]

71. Asgari, N. Die halbfabrikate kleinasiatischen girlanden-sarkophage und ihre herkunft. Archäologischer Anzeiger 1977, 329-380.

72. Ward-Perkins, J.B. The trade in Sarcophagi, in Marble in antiquity, collected papers of J.B. Ward-Perkins. Archaeological Monographs of the British School at Rome; Dodge, H., Ward-Perkins, B., Eds.; British School at Rome: London, UK, 1992; pp. 31-39.

73. Pensabene, P. Il fenomeno del marmo nel mondo Romano. In I Marmi Colorati Della Roma Imperiale; De Nuccio, M., Ungaro, L., Eds.; Marsilio: Roma, Italy, 2002; pp. 3-69.

74. McClure, M.M.H.; Feltoe, C.L. The pilgrimage of Etheria; Society for Promoting Christian Knowledge: London, UK; The Macmillan Company: New York, NY, USA, 1919.

75. Bogdanović, J. The rhetoric of architecture in the Byzantine context: The case study of the Holy Sepulchre/Реторика архитектуре у византијском контексту: пример црквеСветог гроба. Zograf/ЗОГРАФ 2014, 38, 1. Available online: https://lib.dr.iastate.edu/cgi/viewcontent.cgi?referer=https://www.google.com. hk/\&httpsredir=1\&article=1041\&context=arch_pubs (accessed on 20 April 2019).

76. Wright, T. Early Travels in Palestine; H.G. Bohn: London, UK, 1848.

77. Piccirillo, M. The Role of the Franciscans in the Translation of the Sacred Spaces from the Holy Land to Europe. In New Jerusalems: Hierotopy and Iconography of Sacred Spaces; Indrik: Moscow, Russia, 2009; pp. 363-394. Available online: http://hierotopy.ru/contents/NewJerusalems_16_Picirillo_RoleOfFranciscans_2009_EngRus. pdf (accessed on 20 April 2019).

78. Horn, E.; Golubovich, G. Ichnographiae Locorum et Monumentorum Veterum Terrae Sanctae: Accurate Delineatae et Descriptae. E codice Vaticano Lat. No. 9233 excerpsit, adnotavit et edidit (cum 75 figuris et appendice historica ex eodem codice) Hieronymus Golubovich; Typis Sallustianis, 1902. Available online: https:/opac.bibliothecaterraesanctae. org/cgi-bin/koha/opac-search.pl?q=au:Horn,\%20Elzearius (accessed on 20 April 2019).

(C) 2019 by the authors. Licensee MDPI, Basel, Switzerland. This article is an open access article distributed under the terms and conditions of the Creative Commons Attribution (CC BY) license (http://creativecommons.org/licenses/by/4.0/). 